\title{
A Review of Caffeine Adsorption Studies onto Various Types of Adsorbents
}

\author{
Javier Andrés Quintero-Jaramillo (D), Javier Ignacio Carrero-Mantilla $\mathbb{D}$, \\ and Nancy Rocío Sanabria-González
}

\begin{abstract}
Departamento de Ingeniería Química, Universidad Nacional de Colombia Sede Manizales, Campus La Nubia, km 7 vía al Aeropuerto, AA 127, Manizales, Colombia
\end{abstract}

Correspondence should be addressed to Nancy Rocío Sanabria-González; nrsanabriag@unal.edu.co

Received 31 March 2021; Revised 26 June 2021; Accepted 30 June 2021; Published 20 July 2021

Academic Editor: Juei Tang Cheng

Copyright (c) 2021 Javier Andrés Quintero-Jaramillo et al. This is an open access article distributed under the Creative Commons Attribution License, which permits unrestricted use, distribution, and reproduction in any medium, provided the original work is properly cited.

\begin{abstract}
A systematic literature review of publications from 2000 to 2020 was carried out to identify research trends on adsorbent materials for the removal of caffeine from aqueous solutions. Publications were retrieved from three databases (Scopus, Web of Science, and Google Scholar). Words "adsorption AND caffeine" were examined into titles, abstracts, and keywords. A brief bibliometric analysis was performed with emphasis on the type of publication and of most cited articles. Materials for the removal of caffeine were classified according to the type of material into three main groups: organic, inorganic, and composites, each of them subdivided into different subgroups consistent with their origin or production. Tables resume for each subgroup of adsorbents the key information: specific surface area, dose, $\mathrm{pH}$, maximum adsorption capacity, and isotherm models for the removal of caffeine. The highest adsorption capacities were achieved by organic adsorbents, specifically those with granular activated carbon $(1961.3 \mathrm{mg} / \mathrm{g})$ and grape stalk activated carbon $(916.7 \mathrm{mg} / \mathrm{g})$. Phenyl-phosphate-based porous organic polymer (301 mg/g), natural sandy loam sediment ( $221.2 \mathrm{mg} / \mathrm{g})$, composites of MCM-48 encapsulated graphene oxide $(153.8 \mathrm{mg} / \mathrm{g})$, and organically modified clay $(143.7 \mathrm{mg} / \mathrm{g})$ showed adsorption capacities lower than those of activated carbons. In some activated carbons, a relation between the specific surface area (SSA) and the maximum adsorption capacity $\left(Q_{\max }\right)$ was found.
\end{abstract}

\section{Introduction}

Emerging contaminants (ECs) include a wide range of chemical compounds, pharmaceuticals, personal care products, surfactants, industrial additives, plasticizers, and pesticides, among other, and their possible consequences for human health and the environment effects in many cases are still unknown [1-4]. The problem with ECs present in water sources is that plants for purification and wastewater treatment are not able to eliminate them completely, so their persistence in the environment is continuous. Caffeine is continuously detected, due to the advancement and development of instrumental analysis methods [5], and it is considered an indicator of anthropogenic contamination due to its common use by peoples [6]. Caffeine is an EC commonly found in drinking water [7-9], groundwater [4], wastewater [10-12], effluents from wastewater treatment plants [12], rivers, lakes, seas [13], and even in the Antarctic waters [14]. Caffeine is a persistent compound, routinely detected even in countries where coffee is not cultivated but consumed. For example, caffeine concentrations of $0.29 \mu \mathrm{g} / \mathrm{L}$ and $564 \mathrm{ng} / \mathrm{L}$ were determined in drinking water in California (USA) [9] and China [15], respectively. Also, caffeine concentration values in the $1644-3344 \mathrm{ng} / \mathrm{L}$ range have been measured in the Italian river Lambro after receiving the wastewater discharge from the city of Milan [16].

Caffeine is a stimulant of the central nervous system, a chemical compound from the group of methylxanthines (as illustrated in Figure 1), and the mostly consumed psychoactive substance in the world [19]. Caffeine is a naturally occurring alkaloid in approximately 60 plant species, including coffee, tea, and cocoa [20]. It also appears in some 
analgesic and bronchodilator drugs, and even in shampoos $[6,17,18]$.

According to the information in Figure 1, the dipole moment of caffeine is high, increasing with the polarity of the medium that holds it [21]. It means that the positive charge of nitrogen in caffeine electrostatically interacts with any negatively polarized functional group $[17,22]$. The pKa and $\mathrm{pH}$ affect the chemical behavior of pollutants, and a protonated form of caffeine will be produced when $\mathrm{pH}<\mathrm{pKa}$ $[23,24]$. The $\mathrm{pKa}$ and $\mathrm{pH}$ affect the chemical behavior of contaminants, so a protonated form of caffeine will be produced when $\mathrm{pH}<\mathrm{pKa}$.

Chemical treatments for emerging contaminants in water, as caffeine, include ozonation, photo-Fenton processes, photoelectrolysis, and electrochemical oxidation $[15,17,25,26]$. However, these technologies tend to consume high energy and do not achieve a complete mineralization [27]. In contrast, adsorption is efficient, inexpensive, versatile, and environmentally friendly. Adsorption is widely used to remove contaminants in water, especially those that are not biodegradable such as heavy metals and ECs, being caffeine one of them [28-32]. Recent proposals for the removal of caffeine include batch and fixed bed adsorption treatments [26, 33]. Powdered activated carbon (PAC) and granular activated carbon (GAC) have been the most widely used adsorbents due to their high specific surface area and chemical surface properties.

Adsorption is a surface phenomenon, where contaminants dissolved in a liquid phase (adsorbate) interact with a porous solid surface (adsorbent). Generally, the adsorbent surface contains functional groups that allow physical or chemical interaction with the adsorbates present in the fluid [34]. In industrial processes, the contaminated fluid passes through a fixed bed where solid adsorbate particles retain the contaminant. When the bed becomes almost saturated, it regenerates inducing desorption of the adsorbate by heating or other methods, so the adsorbent becomes ready for another adsorption cycle [35]. Adsorption is influenced by several factors, including $\mathrm{pH}$, ionic strength, temperature, amount of adsorbent, particle size, contact time, initial solute concentration, specific surface area, and stirring speed [36-38]. The selection of the operating ranges for these factors is essential in the study of the adsorption process [39].

Interest in the use of adsorbents for the removal of caffeine from aqueous solutions has led to the publication of several reviews on topics related to the very same purpose of this paper. Anastopoulos et al. [40] published a review focusing on emerging contaminants such as caffeine, nicotine, and amoxicillin. That review covered the toxic effect of caffeine in humans and animals and described some of the main adsorbents used for its removal. Isothermal and kinetic models for the analysis of caffeine adsorption were also presented, as well as the maximum adsorption capacity and possible adsorption mechanisms. Rigueto et al. [17] prepared a review on methods for removing caffeine from aqueous solutions and real effluents, examining major findings and limits for each process. The research concluded that, despite encouraging application trends, current technologies for

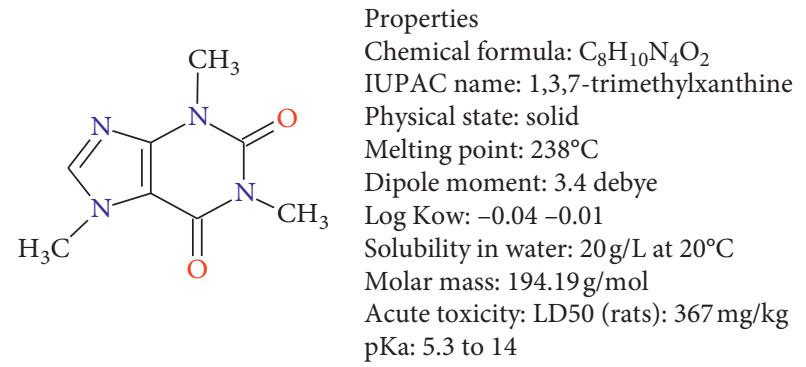

FIgURE 1: Chemical structure and properties of caffeine [17, 18].

caffeine removal have significant limitations, including the complexity of adsorption mechanisms, quantification of contaminants in real effluents, and the low sustainability of the technique. Finally, Bachmann et al. [41] performed a systematic review of the removal of caffeine by adsorption, emphasizing on the evolution of adsorbents used and the kinetic, equilibrium, and thermodynamic studies. The pseudo-second-order (kinetic model) and the Langmuir isotherm models yield the best fit of the experimental data in most studies. On the other hand, our review presents a brief bibliometric analysis of publications of the last two decades, a classification of adsorbents in three groups, including a novel analysis of the process variables $(\mathrm{pH}$ and mass of adsorbent), characterization of the adsorbent (SSA), and the maximum adsorption capacity $\left(Q_{\max }\right)$.

Current trends in caffeine adsorption point the development of materials with adsorbent properties (affinity for the pollutant and high specific surface area), which are abundant and inexpensive. In this sense, the strengthening of scientific research related to the application of new adsorbent materials for the removal of caffeine, contributes to the implementation of clean and environmentally friendly industrial technologies and processes [32, 40, 42, 43]. This document provides a systematic review of literature about caffeine adsorption, presenting the diversity of adsorbents used in research reported in the last two decades, as well as a brief bibliometric analysis. An analysis of the results of the specific surface area of adsorbents was performed, as well as the variables that affect the adsorption process, specifically $\mathrm{pH}$ and adsorbent mass $\mathrm{pH}$ is commonly controlled and evaluated in studies of caffeine adsorption). The results of the maximum adsorption capacities and their adjustments to the model's adsorption isotherms are also presented. This review article will allow researchers to identify the types of adsorbents mostly used for caffeine adsorption in aqueous medium, in addition to adsorption conditions such as adsorbent dose and $\mathrm{pH}$. An analysis of the maximum adsorption capacity $\left(Q_{\max }\right)$ and its relationship with the specific surface area (SSA) of each adsorbent is also shown to determine the performance of the different types of materials used for adsorption.

\section{Materials and Methods}

A systematic literature review of publications (research articles, review articles, book, book chapters, and conference papers) from 2000 (January 1) to 2020 (July 29) was carried out to identify the research trends on caffeine adsorption from 
aqueous solutions, emphasizing the adsorbent materials. During the period 2000-2020, there was an increase in the number of publications on adsorption of different ECs and, although caffeine is mentioned, the first found document that studies caffeine adsorption was published in 2004 [44].

The references were obtained from three search and indexing databases: Scopus, Web of Science, and Google Scholar, which together cover approximately $95 \%$ of the publications worldwide. Scopus indexes the largest number of journals (20\% more coverage than WoS), but WoS performs a more open search so the filters had to be more specific and personalized $[45,46]$. These databases included research articles, review articles, books, book chapters, and conference papers. The search was performed in the title, abstract, and keywords of publications. For search equation "caffeine AND adsorption," 528 results were found.

The 528 preliminary results were manually filtered to remove repeated articles in the databases, to exclude publications that were not within the scope of the present work, and most importantly, to identify the most relevant publications. Finally, 133 publications were used for the preparation of this review, mainly journal articles on environmental sciences, chemistry, chemical engineering, engineering, and material sciences.

\section{Results and Discussion}

3.1. BriefBibliometric Analysis. A bibliometric analysis of the 133 publications selected in the search strategy was performed. Figure 2 shows the number of publications on caffeine adsorption per quadrennium from 2004 to 2020 . The period between 2012 and 2019 corresponds to $82.7 \%$ of the total number of publications, which suggests that it is a current research topic. For the year 2020 (until July 29) there are 11 publications, a similar value to the number of publications between 2004 and 2011.

The distribution of publications in Table 1 shows that most publications are research articles, concentrated in the areas of are chemistry, environmental science, and chemical engineering, which add up to $56.3 \%$ of the total number of publications. Most of the publications (52.8\%) come from three countries: China, Spain, and the USA. Besides, 93.8\% of all publications are published in English, while $4.9 \%$ in Chinese, and the remaining in other languages: Spanish, French, Japanese, German, Portuguese, and Italian. Twothirds of the publications on caffeine adsorption are concentrated on four journals: Science of the Total Environment (23.1\%), Chemosphere (18.7\%), Environmental Science (13.2\%), and Chemical Engineering Journal (12.1\%). Also, a ranking of institutions per number of publications on caffeine adsorption is shown in Table 2.

The ten most cited publications are listed in Table 3, eight of them describe remotion with carbonaceous adsorbents: graphene nanoplatelets, activated carbons, and carbon xerogels. The remaining two publications describe the application of low-cost adsorbents: carbon fibers prepared from pineapple plant leaves, and natural sediments.

To conclude the bibliometric analysis, the cloud shown in Figure 3 summarizes the appearance of keywords in the

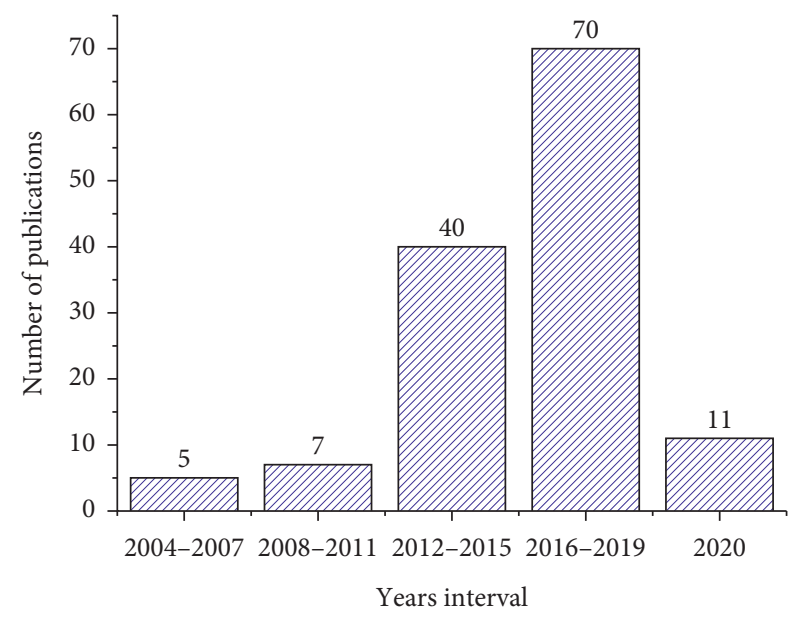

FIGURE 2: Number of publications related to the removal of caffeine from water using adsorption per quadrennium.

TABLE 1: Distribution of publications by type, area, and country.

\begin{tabular}{lccccc}
\hline Type & $(\%)$ & Area & $(\%)$ & Country & $(\%)$ \\
\hline Article & 91.7 & Chemistry & 25.7 & China & 23.3 \\
Review & 4.0 & Environmental Science & 17.3 & Spain & 17.5 \\
Conference & 2.8 & Chemical Engineering & 13.3 & USA & 12.0 \\
Other* & 1.5 & Biochemistry & 11.1 & Brazil & 8.4 \\
Book & 0.0 & Materials Science & 7.5 & France & 5.5 \\
Book chapter & 0.0 & Engineering & 6.4 & Other & 33.3 \\
& \multicolumn{7}{c}{ Other } & 18.7 & & \\
\end{tabular}

${ }^{*}$ Data paper, book paper.

TABLE 2: Ranking of academic institutions by number of publications (NP).

\begin{tabular}{lccc}
\hline Rank & Institution & Country & NP \\
\hline 1 & Complutense University of Madrid & Spain & 10 \\
2 & University of Lisbon & Portugal & 8 \\
3 & Xi'an University of Architecture and & China & 6 \\
4 & Technology & & \\
5 & University of South Carolina (USA) & USA & 3 \\
6 & University of Cyprus & Cyprus & 3 \\
\hline
\end{tabular}

publications. The five most used keywords were adsorption (102 times), caffeine (94 times), water pollutants (54 times), drug (21 times), and activated carbon (19 times). Therefore, this word cloud illustrates the interest in water and wastewater treatment and the use of adsorbents such as activated carbons for the removal of pharmaceutical products (caffeine, ibuprofen, diclofenac, and carbamazepine). The term $\mathrm{pH}$ also stands out, indicating that it is one of the most frequently studied variables in caffeine adsorption processes, being a keyword in 20 of the 133 publications. Finally, the appearance of kinetic and isotherm highlights the interest in understanding the caffeine adsorption mechanism.

3.2. Classification of Adsorbents. All the adsorbents mentioned in the publications follow the common definition, i.e., solid materials with micro- and mesopores that can take a 
TABLE 3: Ranking of most cited research articles (excluding reviews).

\begin{tabular}{|c|c|c|c|c|}
\hline Rank & Title & $\begin{array}{l}\text { Number of } \\
\text { citations }\end{array}$ & Year & Ref \\
\hline 1 & $\begin{array}{c}\text { Adsorption characteristics of selected hydrophilic and hydrophobic micropollutants in water } \\
\text { using activated carbon }\end{array}$ & 179 & 2014 & [47] \\
\hline 2 & Adsorption of pharmaceutical pollutants onto graphene nanoplatelets & 129 & 2014 & [48] \\
\hline 3 & Competitive adsorption studies of caffeine and diclofenac aqueous solutions by activated carbon & 115 & 2014 & [49] \\
\hline 4 & $\begin{array}{l}\text { Potential for biodegradation and sorption of acetaminophen, caffeine, propranolol and } \\
\text { acebutolol in lab-scale aqueous environments }\end{array}$ & 107 & 2010 & [50] \\
\hline 5 & Removal of caffeine and diclofenac on activated carbon in fixed bed column & 97 & 2012 & [30] \\
\hline 6 & $\begin{array}{c}\text { Chemical-activated carbons from peach stones for the adsorption of emerging contaminants } \\
\text { in aqueous solutions }\end{array}$ & 87 & 2015 & [51] \\
\hline 7 & $\begin{array}{l}\text { Synthesis of carbon xerogels and their application in adsorption studies of caffeine and } \\
\text { diclofenac as emerging contaminants }\end{array}$ & 75 & 2015 & [52] \\
\hline 8 & $\begin{array}{l}\text { Sorption/desorption of non-hydrophobic and ionisable pharmaceutical and personal care } \\
\text { products from reclaimed water onto/from a natural sediment }\end{array}$ & 73 & 2013 & [53] \\
\hline 9 & Adsorption of caffeine on mesoporous activated carbon fibers prepared from pineapple plant leaves & 67 & 2018 & [54] \\
\hline 10 & $\begin{array}{l}\text { Activated carbons prepared from industrial pre-treated cork: Sustainable adsorbents for } \\
\text { pharmaceutical compounds removal }\end{array}$ & 64 & 2014 & [55] \\
\hline
\end{tabular}

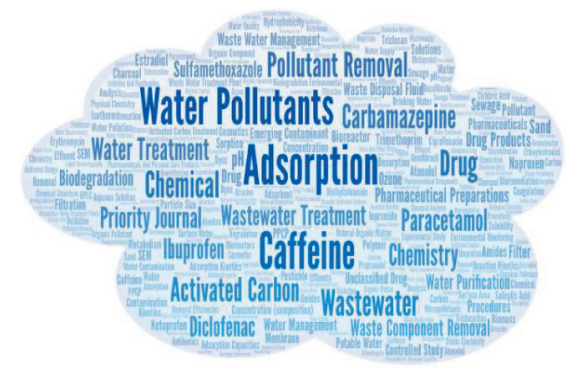

Figure 3: Word cloud view of the most frequently used keywords for caffeine adsorption.

significant part of the material volume [56, 57]. Figure 4 shows the classification of adsorbents in three groups (with their respective subgroups):

Organic (68.3\% of publications): carbon-based, they can be of natural origin such as agricultural residues and biochar or of synthetic origin such as polymers. Some of them are of mixed origin, such as biopolymers obtained from chitosan compounds [58].

Inorganic (20.8\%): mainly minerals, for example, silica, metal oxides, and materials such as mineral clays, sediments, and soils. By origin, they can be synthetic or natural [59].

Composite (10.9\%): hybrids that combine two or more materials, of organic and/or inorganic type [60]. This group of adsorbents have been investigated with promising results for the removal of dyes [61, 62], heavy metals $[63,64]$, and emerging contaminants $[65,66]$.

For each subgroup of adsorbents, the following parameters were analyzed: specific surface area (SSA), adsorbent dose, $\mathrm{pH}$, maximum adsorption capacity, and isothermal and kinetic models for caffeine adsorption to which the data were adjusted.

3.2.1. Organic Adsorbents. The summary of characteristics of the subgroups of organic adsorbents and conditions of the adsorption process are shown in Table 4 (activated carbons),

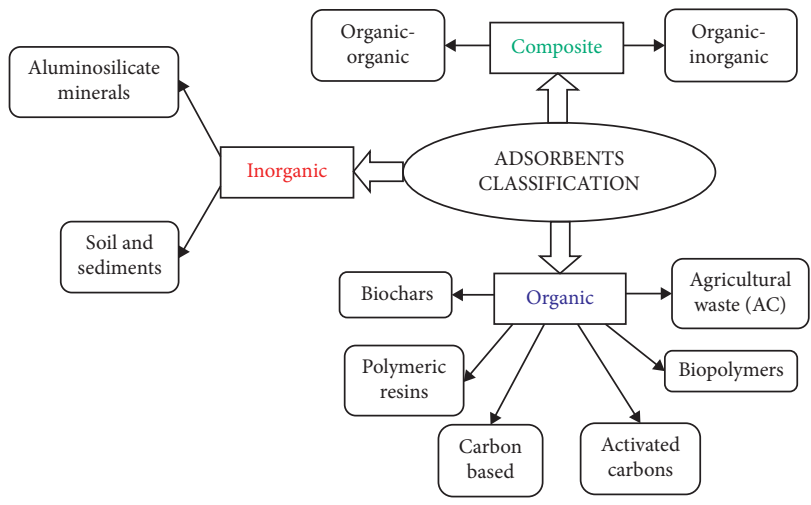

FIgURE 4: Classification of adsorbents for caffeine adsorption.

Table 5 (carbon-based), Table 6 (agricultural wastes directly as adsorbents or as precursors for activated carbons), Table 7 (biochar), and Table 8 (polymeric resins and biopolymers). Most of the organic adsorbents in this group are activated carbons (Table 4), either powdered (PAC) or granular (GAC). Activated carbons have a high specific surface area, between 578 and $2431 \mathrm{~m}^{2} / \mathrm{g}$ and good surface chemical properties, but they are expensive, and some of them cannot be regenerated [67]. Their adsorption capacity range is very wide, including low $(161 \mathrm{ng} / \mathrm{g}-396 \mu \mathrm{g} / \mathrm{g})$, medium (4.95-219.2 mg/g), and high (271-1961.26 mg/g) values. The $\mathrm{pH}$ described for caffeine adsorption varies between 3 and 9 for this subgroup of adsorbents, with the highest $Q_{\max }$ values obtained at $\mathrm{pH} 7$.

The carbon-based adsorbents subgroup (Table 5) covers materials that come from carbon but differ from activated carbons, such as xerogels, nanotubes, nanofibers, and graphene. Carbon-based adsorbents have a smaller specific surface area and removal capacity than activated carbons, although they are considered materials with potential application for the removal of caffeine [48, 72, 82-84]. Carbon cloth has both the highest SSA and $Q_{\max }$ values in this subgroup, $1560 \mathrm{~m}^{2} / \mathrm{g}$ and $369.0 \mathrm{mg} / \mathrm{g}$, respectively [85]. 
TABLE 4: Summary of characteristics of activated carbons and conditions of the adsorption process.

\begin{tabular}{|c|c|c|c|c|c|c|}
\hline Type & SSA $\left(\mathrm{m}^{2} / \mathrm{g}\right)$ & Dose $(\mathrm{mg} / \mathrm{L})$ & $\mathrm{pH}$ & $Q_{\max }(\mathrm{mg} / \mathrm{g})$ & IM & Ref \\
\hline GAC & 1100 & 1000 & 7 & 1961.3 & Langmuir & [68] \\
\hline Hydrothermal carbons & 2431 & 200 & 7 & 448.4 & Langmuir & [69] \\
\hline$F-400$ & - & 60 & 7 & 393.7 & Langmuir & [70] \\
\hline AC from polymer waste & 1900 & 100 & 5.65 & 363.6 & Langmuir & [67] \\
\hline GAC & 917 & 6.7 & 5 & 271.1 & Langmuir & [71] \\
\hline PAC & 997 & - & 3 & 271.0 & Langmuir & {$[72]$} \\
\hline F-400 & 1102 & - & 6.5 & 219.2 & - & [33] \\
\hline F- 400 & 997 & 800 & 6.2 & 214.7 & - & [73] \\
\hline F-400 & 997 & - & 6.3 & 190.9 & Freundlich & [49] \\
\hline GAC & 997 & 800 & - & 155.6 & Freundlich & [30] \\
\hline GAC & 578 & 50 & 6 & 112 & Toth & [74] \\
\hline PAC & 882.6 & 10 & 4 & 71.7 & Freundlich & [75] \\
\hline GAC & - & 10000 & 6 & 31.94 & Langmuir & [76] \\
\hline PAC & 710.4 & 20 & 8 & 12.63 & Langmuir & [77] \\
\hline PAC & - & 500 & 7 & 4.95 & - & [78] \\
\hline GAC & - & 900 & 7.9 & $396 \mu \mathrm{g} / \mathrm{g}$ & Langmuir & [79] \\
\hline PAC & 1256 & 540 & - & $27 \mu \mathrm{g} / \mathrm{g}$ & Freundlich & [80] \\
\hline GAC & 1000 & 3000 & 7.3 & $161 \mathrm{ng} / \mathrm{g}$ & - & [81] \\
\hline
\end{tabular}

TABLE 5: Summary of characteristics of carbon-based adsorbents and conditions of the adsorption process.

\begin{tabular}{|c|c|c|c|c|c|c|}
\hline Type & SSA $\left(\mathrm{m}^{2} / \mathrm{g}\right)$ & Dose $(\mathrm{mg} / \mathrm{L})$ & $\mathrm{pH}$ & $Q_{\max }(\mathrm{mg} / \mathrm{g})$ & $\mathrm{IM}$ & Ref \\
\hline Carbon cloth & 1560 & 12 & 7.45 & $369.0(1.9 \mathrm{mmol} / \mathrm{g})$ & Langmuir & [85] \\
\hline Carbon xerogels treated with urea solution & 435 & 60 & - & 182.5 & Sips & [52] \\
\hline Carbon xerogel modified with $\left(\mathrm{CH}_{3} \mathrm{COO}\right)_{2} \mathrm{Cu}$ & 546 & 20 & 2 & 107.0 & Langmuir & [87] \\
\hline Carbon nanotubes & 199.1 & - & 3 & 41.6 & Langmuir & {$[72]$} \\
\hline Carbon nanofibers & 162.2 & - & 3 & 28.3 & Langmuir & [72] \\
\hline Graphene & 570.2 & 100 & 7.5 & 22.7 & Langmuir & [84] \\
\hline Graphene nanoplatelets & 635.2 & 200 & - & 19.72 & - & [48] \\
\hline Commercial column $\mathrm{C}_{18}$ & - & 200 & - & 11.35 & Freundlich & [82] \\
\hline Carbon nanotubes & 13 & 50 & 7 & 10.1 & Toth & [86] \\
\hline Carbon nanotubes & 360 & - & - & 8.14 & - & [83] \\
\hline
\end{tabular}

TABLE 6: Summary of characteristics of agricultural wastes, directly as adsorbents or as precursors for activated carbon, and conditions of the adsorption process.

\begin{tabular}{|c|c|c|c|c|c|c|}
\hline Source & SSA $\left(\mathrm{m}^{2} / \mathrm{g}\right)$ & Dose $(\mathrm{mg} / \mathrm{L})$ & $\mathrm{pH}$ & $Q_{\max }(\mathrm{mg} / \mathrm{g})$ & IM & Ref \\
\hline Grape stalk-AC & 1099.86 & - & 4 & 916.7 & Sips & [92] \\
\hline Pine activated-AC & 945 & 6 & 5 & 500 & Langmuir & [91] \\
\hline Biodiesel production waste-AC & 1165 & 6 & 5 & 296.3 & Langmuir & [97] \\
\hline Peach stones modified by oxidation-AC & 959 & 120 & 6.3 & 270.0 & Sips & {$[51]$} \\
\hline Peach stones-AC & 1216 & 120 & 6.3 & 260.0 & Sips & {$[51]$} \\
\hline Eragrostis plana (Nees leaves)-AC & 1250 & 70 & 7 & 235.5 & Liu & [95] \\
\hline Dende coco-AC & 755 & 10 & 3 & 212.3 & Langmuir & [94] \\
\hline Babassu coco-AC & 980 & 10 & 3 & 186.9 & Langmuir & [94] \\
\hline Biomass impregnated $\mathrm{KOH}-\mathrm{AC}$ & 1597 & 10 & - & 181.23 & Freundlich & [98] \\
\hline Pineapple plant leaves-AC & 1031 & 25 & 7 & 155.5 & Langmuir & [54] \\
\hline Industrial pretreated cork-AC & 750 & 6 & 5 & 153.4 & - & [55] \\
\hline Peach stones under helium-AC & 1064 & 120 & 4.8 & 260 & Sips & [51] \\
\hline Biomass-AC & 1373 & 10 & - & 102.04 & Langmuir & [98] \\
\hline Luffa cylindrica-AC & - & 50 & 4 & 59.9 & Langmuir & [99] \\
\hline Acacia mangium wood-AC & - & 3000 & 7.7 & 30.3 & - & [96] \\
\hline Elaeis guineensis-AC & 407.66 & 200 & 2 & 13 & Langmuir & [93] \\
\hline Date stone (Phoenix dactylifera)-AC & - & 8000 & - & 8.7 & - & {$[100]$} \\
\hline Eichhornia crassipes-water hyacinth & - & 1200 & 2 & 2.49 & Langmuir & [101] \\
\hline
\end{tabular}


TABLE 7: Summary of characteristics of biochar adsorbents and conditions of the adsorption process.

\begin{tabular}{|c|c|c|c|c|c|c|}
\hline Biochar base & SSA $\left(\mathrm{m}^{2} / \mathrm{g}\right)$ & Dose $(\mathrm{mg} / \mathrm{L})$ & $\mathrm{pH}$ & $Q_{\max }(\mathrm{mg} / \mathrm{g})$ & IM & Ref \\
\hline Fique bagasse & 211.7 & 10000 & 5.9 & 40.2 & - & [107] \\
\hline Pistachio shells & 20 & 10 & - & 22.6 & Langmuir & [108] \\
\hline Gliricidia sepium & 216.4 & 1000 & 4.5 & 16.26 & Freundlich & [102] \\
\hline Tea-waste & 576 & 1 & 3.5 & 15.4 & Freundlich & [109] \\
\hline Rice husk & 144 & 50 & 5 & 8 & Langmuir & {$[110]$} \\
\hline Pine needles & - & 50 & 4 & 6.54 & Langmuir & [111] \\
\hline
\end{tabular}

TABLE 8: Summary of characteristics of polymeric resins and biopolymers and conditions of the adsorption process.

\begin{tabular}{|c|c|c|c|c|c|c|}
\hline Adsorbent & SSA $\left(\mathrm{m}^{2} / \mathrm{g}\right)$ & Dose $(\mathrm{mg} / \mathrm{L})$ & $\mathrm{pH}$ & $Q_{\max }(\mathrm{mg} / \mathrm{g})$ & IM & Ref \\
\hline \multicolumn{7}{|l|}{ Polymeric resin } \\
\hline P-POP-2 & 581 & 200 & 5 & 301 & Langmuir & {$[60]$} \\
\hline P-POP-1 & 714 & 200 & 5 & 245 & Langmuir & [60] \\
\hline GS18 (MAR) & $480-520$ & 33333 & - & 239.9 & Freundlich & {$[112]$} \\
\hline XDA-200 & 1000 & 40000 & - & 209.0 & Freundlich & {$[113]$} \\
\hline $\mathrm{D} 101$ & 710.1 & 1000 & - & 75.2 & Langmuir & {$[114]$} \\
\hline Amberlite ${ }^{\circledR}$ XAD-7 & 450 & - & 7 & 58.32 & Langmuir & [115] \\
\hline MIP & - & 20000 & - & 39.65 & - & [82] \\
\hline Copolymer divinylbenzene-acrylonitrile & 632 & 4800 & - & 19.3 & Freundlich & {$[116]$} \\
\hline NIPAAm-based hydrogels & - & - & - & $19 \mathrm{mg} / \mathrm{mL}$ & Langmuir & {$[44]$} \\
\hline Oasis $^{\circledR}$ HLB & 800 & 200 & - & $18.64(96 \mathrm{mmol} / \mathrm{kg})$ & Langmuir & {$[117]$} \\
\hline Polyvinylpolypyrrolidone & - & 500 & 7 & 11.09 & Langmuir & {$[118]$} \\
\hline Macroporous crosslinked polyvinyl alcohol & $700-800$ & 500 & - & 7.73 & - & [119] \\
\hline Resinex/SR 5500 & 861 & $5.4 \mathrm{~mL} / \mathrm{L}$ & 7 & $256.4 \mathrm{ng} / \mathrm{g}$ & Langmuir & {$[120]$} \\
\hline \multicolumn{7}{|l|}{ Biopolymer } \\
\hline Chitosan & 3.6 & 1000 & 7 & 0.00617 & Langmuir & {$[121]$} \\
\hline
\end{tabular}

Carbon xerogels and carbon cloth show adsorption capacities of 107.0 and $369.0 \mathrm{mg} / \mathrm{g}$, respectively $[52,85]$, while carbon nanotubes and commercial column C18 show adsorption capacities in the range of 8.14 to $41.6 \mathrm{mg} / \mathrm{g}$ and less specific surface area $[72,82,83,86]$. Following Table 5, the most used $\mathrm{pH}$ for removal of caffeine is close to neutrality, except for carbon xerogel modified with $\left(\mathrm{CH}_{3} \mathrm{COO}\right)_{2} \mathrm{Cu}$, nanotubes, and carbon nanofibers, where the optimal $\mathrm{pH}$ at values of 2 and 3 was found $[72,87]$.

Agricultural wastes (Table 6) are low-cost natural raw materials, abundantly available. The agricultural waste subgroup includes them used directly as adsorbents and the activated carbons produced from them, which have improved properties, mainly specific surface area (407.66-1099.86 $\mathrm{m}^{2} / \mathrm{g}$ ) and adsorption capacity for caffeine (8.7-916.7 mg/g).

Activated carbons are produced from agricultural wastes by controlled pyrolysis combined with chemical treatment, taking advantage of its high carbon content and low percentage of inorganic matter [88-90]. Activated carbons from grape stalk and pine have the highest SSA and adsorption capacity [91, 92], while those obtained from other agricultural wastes such as peach stones, dende coco, and babassu coco have a $Q_{\max }$ between 186.9 and $270 \mathrm{mg} / \mathrm{g}$, which is anyway higher than those of other carbon-based adsorbents such as nanotubes $(41.6 \mathrm{mg} / \mathrm{g})$ and nanofibers $(28.3 \mathrm{mg} / \mathrm{g})$ [72].

Regarding $\mathrm{pH}$, acidic $\mathrm{pHs}$ in the range 2-5 tend to yield the best results, such as produced as follows: at $\mathrm{pH} \mathrm{2,} \mathrm{a}$ maximum adsorption capacity of $13 \mathrm{mg} / \mathrm{g}$ for the activated carbon obtained from Elaeis guineensis (palm oil) [93]; at $\mathrm{pH}$ 3, a $Q_{\max }$ of $212.3 \mathrm{mg} / \mathrm{g}$ for biomass-derived activated carbons (dende coco and babassu coco) [94]; at $\mathrm{pH} 4$, a $Q_{\max }$ of $916.7 \mathrm{mg} / \mathrm{g}$ for grape stalk activated carbon [92]; and at $\mathrm{pH} 5$, a $Q_{\max }$ of $500 \mathrm{mg} / \mathrm{g}$ for pine activated carbon with $\mathrm{K}_{2} \mathrm{CO}_{3}$ [91]. For $\mathrm{pH}$ values between 6.3 and 7.7, a $Q_{\max }$ of 30.3 to $270 \mathrm{mg} / \mathrm{g}$ has been reported, being the case of activated carbons obtained from residues of Acacia mangium wood, pineapple plant leaves, Eragrostis plana, and peach stones [51, 54, 95, 96].

Biochar adsorbents (Table 7) are obtained from pyrolysis of animal or vegetable biomass at temperatures between 300 and $700^{\circ} \mathrm{C}$ with a low oxygen amount [102-104]. The interest in biochar adsorbents has recently surged due to their high specific surface area and adsorption capacity $[105,106]$. The adsorption capacities of the biochar adsorbent subgroup (Table 7) are between 6.54 and $40.2 \mathrm{mg} / \mathrm{g}$, well below values of activated carbons but comparable with those of carbonbased adsorbents such as nanoplatelets [48], carbon nanofibers [72], and graphene [84]. The $\mathrm{pH}$ for caffeine adsorption in this subgroup of adsorbents is slightly acidic, with values between 3.5 and 5.9.

Polymeric resins, solid or liquid, are usually based on polystyrene, polyacrylamide, and polyvinyl alcohol. Recent improvements in polymerization processes have achieved enough resistance and chemical stability to make them suitable for the removal of contaminants from water [60]. Summary of characteristics of polymeric resins and 
biopolymers and conditions of the adsorption process are described in Table 8 . The $Q_{\max }$ in Table 8 is not very high (between $256.4 \mathrm{ng} / \mathrm{g}$ to $301 \mathrm{mg} / \mathrm{g}$ ) compared with the $Q_{\max }$ of activated carbons, but the high specific areas of the polymer resins $\left(450-1000 \mathrm{~m}^{2} / \mathrm{g}\right)$ suggest that they could be very effective for the adsorption of other contaminants.

Biopolymer adsorbents are polymers obtained from algae, plants, or agro-industrial products, hence the bio prefix. The most common one is chitosan, which is obtained from chitin, an abundant mucopolysaccharide and the support material of crustaceans and insect exoskeletons. It is biocompatible, biodegradable, and nontoxic and, most importantly, has good adsorption properties [122]. Chitosan and other biopolymers have been evaluated with good results for removal of contaminants such as metals and dyes, but their performance for caffeine adsorption is not promising [123-125]. The costs of obtaining biopolymers are very high and show no advantages over other adsorbents investigated for the removal of caffeine, except when used with other materials to form composites $[123,126]$.

3.2.2. Inorganic Adsorbents. This kind of adsorbents can be classified into two subgroups: aluminosilicate minerals (Table 9) and soil and sediment adsorbents (Table 10); and the most used for the removal of caffeine have been clay minerals (natural and modified), zeolites, soils, and sediments. It is also possible to change the naturally hydrophilic character of smectite clay minerals into organophilic, making them act as adsorbents for organic compounds. The intercalation of surfactant cations (quaternary ammonium salts) into layers of clay minerals not only changes the surface properties but also increases the interlamellar distance (basal spacing) of the layers, thus easing the adsorption of organic molecules [42, 59, 127-131]. Bentonite (a montmorillonite) and saponite are the most frequently used clays as caffeine adsorbents.

Regarding aluminosilicates (Table 9), smectite minerals-such as montmorillonite and saponite and their modifications, organoclays, or thermally treated smectites-show a good caffeine adsorption capacity $(99.0-143.7 \mathrm{mg} / \mathrm{g})$, with the advantage of being abundant and low-cost materials $[22,43,130,131]$. Although aluminosilicates have a low SSA in comparison with activated carbons, sepiolite and bentonite have a good adsorption capacity for caffeine. For example, a sepiolite with a specific surface area of $221 \mathrm{~m}^{2} / \mathrm{g}$ has a maximum adsorption capacity of $48.7 \mathrm{mg} / \mathrm{g}$ [132], and bentonite with a low SSA $\left(64.31 \mathrm{~m}^{2} / \mathrm{g}\right)$ has a $Q_{\max }$ of $42.5 \mathrm{mg} / \mathrm{g}$ [127]. The $\mathrm{pH}$ for caffeine adsorption in the subgroup of aluminosilicate mineral adsorbents (Table 9) varies between 6.0 and 6.6, values close to neutrality.

Soil and sediments (Table 10) are sandy and silty minerals obtained from aquifers and rivers. They are adsorbents of water contaminants, preferably those with a low content of organic matter and clay, which increase the specific surface area $[50,53,136]$. The maximum adsorption capacities of soils and sediments (in the range of $292 \mu \mathrm{g} / \mathrm{kg}$ to $221.2 \mathrm{mg} / \mathrm{g}$ ) tend to be lower than the $Q_{\max }$ of the other adsorbent types covered in this review. It has been also described that the equilibrium time among this group of adsorbents and adsorbates is very long, in some cases more than $24 \mathrm{~h}$, which would explain why sediments do not retain ECs in rivers and water bodies $[137,138]$. The $\mathrm{pH}$ for caffeine adsorption in this subgroup of inorganic adsorbents (Table 10) varies between 6.0 and 7.98, values close to neutrality.

3.2.3. Composites. This subgroup comprises adsorbents formed by the combination of materials of two or more types, such as organic and inorganic, to improve their morphological characteristics, specific surface area, and adsorption capacity $[60,109]$. They fall in two categories: organic-organic composites (Table 11) and organic-inorganic composites (Table 12). Composite adsorbents have been investigated with promising results for the removal of dyes [61, 62], heavy metals [64], and emerging contaminants $[65,66]$.

Organic-organic composites used for the adsorption of caffeine include chitosan-graphene, chitosan-reduced graphene oxide, and chitosan-waste coffee-grounds. The synthesis of composites notably improves the specific surface area of adsorbents and increases the caffeine adsorption capacity. For example, when chitosan was used as an individual adsorbent, a specific surface area of $3.6 \mathrm{~m}^{2} / \mathrm{g}$ and a maximum adsorption capacity of $0.0062 \mathrm{mg} / \mathrm{g}$ were obtained [121], while the combination with graphene yields $214 \mathrm{~m}^{2} / \mathrm{g}$ and $14.8 \mathrm{mg} / \mathrm{g}$, respectively [140]. For the chitosan-reduced graphene oxide composite, the SSA is not reported, but the $Q_{\max }$ of caffeine was $63.6 \mathrm{mg} / \mathrm{g}$ [126]. The resin resulting from the copolymerization of $\mathrm{N}$-vinyl-2-pyrrolidinone (PVC), ethylene glycol dimethacrylate (DEGMA), and triallyl isocyanurate (TAIC) has also been tested as a caffeineadsorbent material, although with low removal capacity $(2 \mathrm{mg} / \mathrm{g})$ [141]. The $\mathrm{pH}$ range for caffeine adsorption on chitosan-graphene composites is $6-7$, values close to neutrality.

Among organic-inorganic composites (Table 12), the best caffeine adsorbents found were MCM-48-GO, PSt/O$\mathrm{TiO}_{2}$, and copper oxide nanoparticles on activated carbon [142-144]. The $\mathrm{pH}$ range for caffeine adsorption on the organic-inorganic composites was between 4 and 7, except for MgAl-LDH/biochar, with a $\mathrm{pH}$ of 12 .

In general, in the group of organic adsorbents, activated carbons tend to have the highest specific surface area and $Q_{\max }$. Most of them are microporous in structure, although mesopores and macropores are also present, with a size distribution that mainly depends on three factors: origin of the raw material, type of activation, and duration of the activation process. The capacity of an activated carbon to retain a given substance depends not only depends on its specific surface area but also on the proportion of internal pores that the carbon has and the size of these pores (a suitable pore size should be between 1 and 5 times the diameter of the molecule to be retained) [150]. Adsorbents obtained from agricultural residues, biochar, and polymeric resins are modified by different processes developing porous structures that notably improve the maximum adsorption capacities, as it happens with the AC obtained from 
TABLE 9: Summary of characteristics of aluminosilicate mineral adsorbents and conditions of the adsorption process.

\begin{tabular}{|c|c|c|c|c|c|c|}
\hline Adsorbent & SSA $\left(\mathrm{m}^{2} / \mathrm{g}\right)$ & Dose $(\mathrm{mg} / \mathrm{L})$ & $\mathrm{pH}$ & $Q_{\max }(\mathrm{mg} / \mathrm{g})$ & IM & Ref \\
\hline Organoclay (montmorillonite) & - & 50 & - & 143.7 & Langmuir & [43] \\
\hline Organoclay (sepiolite) & - & 50 & - & $134.0(0.69 \mathrm{mmol} / \mathrm{g})$ & Langmuir & {$[43]$} \\
\hline Montmorillonite & - & - & - & $122.4(0.63 \mathrm{mmol} / \mathrm{g})$ & Langmuir & {$[22]$} \\
\hline Na-montmorillonite & - & 400 & - & $120.4(0.62 \mathrm{mmol} / \mathrm{g})$ & Langmuir & [131] \\
\hline Montmorillonite (calcinated at $200^{\circ} \mathrm{C}$ ) & - & 4000 & - & $99.0(0.51 \mathrm{mmol} / \mathrm{g})$ & Langmuir & [130] \\
\hline Sepiolite & 221 & 1600 & - & 48.7 & Langmuir & {$[132]$} \\
\hline Bentonite & 64.31 & - & 6.5 & 42.5 & - & [127] \\
\hline Bentonite & 135 & 100 & - & 22.3 & Langmuir & [59] \\
\hline Sepiolite & - & 2500 & - & 20 & Dubinin-Radushkevich & [133] \\
\hline Sepiolite & 221 & - & 6.5 & 19.27 & - & [33] \\
\hline Clinoptilolite & & 100 & 6 & 5.48 & Langmuir & [134] \\
\hline Bentonite & - & 2500 & 6.6 & 3.6 & Freundlich & {$[42]$} \\
\hline Calcined Verde-lodo & - & 500 & - & $8.78 \mu \mathrm{mol} / \mathrm{g}$ & - & [135] \\
\hline Spectrogel & - & 500 & - & $3.27 \mu \mathrm{mol} / \mathrm{g}$ & - & [135] \\
\hline Fluidgel organoclay & - & 500 & - & $2.12 \mu \mathrm{mol} / \mathrm{g}$ & - & [135] \\
\hline Calcined fluidgel & & 500 & - & $2.73 \mu \mathrm{mol} / \mathrm{g}$ & - & [135] \\
\hline
\end{tabular}

TABLE 10: Summary of characteristics of soil and sediment adsorbents and conditions of the adsorption process.

\begin{tabular}{|c|c|c|c|c|c|c|}
\hline Adsorbent & SSA $\left(\mathrm{m}^{2} / \mathrm{g}\right)$ & Dose $(\mathrm{mg} / \mathrm{L})$ & $\mathrm{pH}$ & $Q_{\max }(\mathrm{mg} / \mathrm{g})$ & $\mathrm{IM}$ & Ref \\
\hline Natural sediment & - & 50 & 7.94 & 221.2 & Freundlich & {$[53]$} \\
\hline Subsoil & - & 31.5 & 6 & $7.2 \mu \mathrm{g} / \mathrm{g}$ & - & [138] \\
\hline Sediment & 15.21 & 10 & 7.5 & $444 \mu \mathrm{g} / \mathrm{kg}$ & Langmuir & [136] \\
\hline Sediment & 6.1 & 100 & 7 & $360 \mu \mathrm{g} / \mathrm{kg}$ & Freundlich & {$[50]$} \\
\hline Natural soil & - & 300 & 7.98 & $292 \mu \mathrm{g} / \mathrm{kg}$ & - & [137] \\
\hline Sediment & & 15 & 7.50 & - & Freundlich & [139] \\
\hline
\end{tabular}

TABLE 11: Summary of characteristics of the composite adsorbent organic-organic types and conditions of the adsorption process.

\begin{tabular}{|c|c|c|c|c|c|c|}
\hline Adsorbent & SSA $\left(\mathrm{m}^{2} / \mathrm{g}\right)$ & Dose $(\mathrm{mg} / \mathrm{L})$ & $\mathrm{pH}$ & $Q_{\max }(\mathrm{mg} / \mathrm{g})$ & IM & Ref \\
\hline Chitosan-reduced graphene oxide & - & 3750 & - & 63.6 & - & {$[126]$} \\
\hline Graphene-chitosan & 214 & 25 & 7 & 14.8 & Langmuir & [140] \\
\hline Chitosan/waste coffee-grounds & - & 50 & 6 & 8.21 & Freundlich & [123] \\
\hline PVP-DEGMA-TAIC & 114 & 0.05 & 4 & 2 & Langmuir & [141] \\
\hline
\end{tabular}

TABLE 12: Summary of characteristics of composite adsorbent organic-inorganic types and conditions of the adsorption process.

\begin{tabular}{|c|c|c|c|c|c|c|}
\hline Adsorbent & SSA $\left(\mathrm{m}^{2} / \mathrm{g}\right)$ & Dose $(\mathrm{mg} / \mathrm{L})$ & $\mathrm{pH}$ & $Q_{\max }(\mathrm{mg} / \mathrm{g})$ & IM & Ref \\
\hline MCM-48-GO & - & 40 & 6 & 153.8 & Langmuir & [142] \\
\hline $\mathrm{PSt} / \mathrm{O}-\mathrm{TiO}_{2}$ & 248.5 & 1000 & - & 141.69 & Freundlich & [143] \\
\hline Copper oxide nanoparticles on activated carbon & 640 & 100 & 7 & 41.0 & - & [144] \\
\hline Lignocellulosic residues impregnated with $\mathrm{TiO}_{2}$ & - & 7000 & 7.06 & 37.1 & Langmuir & [145] \\
\hline MgAl-LDH/biochar & 46.43 & 4000 & 12 & 26.2 & Redlich-Peterson & [146] \\
\hline $\mathrm{UiO}-66$ & 1391 & 3 & - & 24.25 & - & [147] \\
\hline Polypyrrole- $\mathrm{Fe}_{3} \mathrm{O}_{4} @ \mathrm{SiO}_{2}$ & 45.08 & 60 & 4 & 16.74 & Langmuir-Freundlich & [148] \\
\hline $\mathrm{Cu}^{2+}$ amino grafted SBA-15 mesoporous silica & - & 15 & 7 & $0.25 \mu \mathrm{g} / \mathrm{g}$ & Freundlich & [149] \\
\hline
\end{tabular}

lignocellulosic materials [55]. Regarding composite-type adsorbents, Delhiraja et al. [140] have used functionalized graphene oxide composites (GO) for the adsorption of caffeine and other pharmaceutical and personal care products. Density functional theory calculations indicated that the adsorption mechanism is typically accompanied by size-related diffusion and a minor contribution of synergetic combination of hydrophobic/hydrophilic, hydrogen bonding, electrostatic, and $\pi-\pi$ interactions.

\section{Final Discussion}

This section presents an analysis of the maximum adsorption capacity of caffeine on each adsorbent subgroup and its relationship with the specific surface area of the material and the $\mathrm{pH}$ at which adsorption was performed. The adsorption of caffeine-like molecules onto activated carbon, its interaction with adsorbents, and the regeneration and reuse of adsorbents for caffeine removal are also analyzed. 
4.1. Maximum Adsorption Capacity. Figure 5 shows the $Q_{\max }$ of caffeine for the adsorbents of each subgroup. Granular activated carbon (MG 1050 from ChiemiVallSpain, SSA of $1100 \mathrm{~m}^{2} / \mathrm{g}$ and an average particle size of $1 \mathrm{~mm}$ ) is the adsorbent with the highest adsorption capacity (1961.3 mg/g) followed by grape stalk activated carbon $(916.7 \mathrm{mg} / \mathrm{g})$ and activated carbon cloth $(369 \mathrm{mg} / \mathrm{g})$. The above three adsorbents are activated carbon-based organic adsorbents, and biochar is one of the organic adsorbents with the lowest $Q_{\max }$. Adsorbents such as natural sediment (221 mg/g) and aluminosilicate minerals $(143.7 \mathrm{mg} / \mathrm{g}$ ) are an option for removal of caffeine, due to their low cost and abundance.

Figure 6 shows the $Q_{\max }-S S A$ relation for the adsorbent subgroups. The highest $Q_{\max }$ values, above $70 \mathrm{mg} / \mathrm{g}$, correspond to activated carbons (carbon-based and from agricultural wastes) followed by polymeric resins and organicinorganic composites, with SSA in the $140-1900 \mathrm{~m}^{2} / \mathrm{g}$ range. A direct relationship between SSA and $Q_{\max }$ was found only for some adsorbents of the activated carbon subgroup.

In the publications covered in this review, the adsorption of caffeine has been performed over a wide $\mathrm{pH}$ range (2-10), although it is customary to operate at $\mathrm{pH}$ values close to neutral, and even some studies do not evaluate the influence of $\mathrm{pH}[47,84,151]$. Figure 7 illustrates how the highest $Q_{\max }$ (activated carbons, included those produced from agricultural wastes) correspond to $\mathrm{pH}$ values between 5 and 7 . It is also observed that the adsorption with carbon-based materials decreases with $\mathrm{pH}$, and their higher $Q_{\max }$ are in the 2$3 \mathrm{pH}$ range. It is important to consider that $\mathrm{pH}$ affects the degree of caffeine ionization and the surface charge of the adsorbent [99]. On some carbonaceous adsorbents, $\mathrm{pH}$ has little effect on caffeine adsorption; however, some studies indicate that caffeine adsorption capacity decreases with higher values of $\mathrm{pH}$ due to electrostatic repulsion [47, 48, 92, 133].

Regarding the adsorbent dose, its effect was not studied in most of the articles reviewed, but it was set in a very wide range, from $0.05 \mathrm{mg} / \mathrm{L}$ to $40000 \mathrm{mg} / \mathrm{L}$, while the value used for the highest $Q_{\max }(1961.3 \mathrm{mg} / \mathrm{L}$, with activated carbon) was $1000 \mathrm{mg} / \mathrm{L}$ [68].

For most of the organic adsorbent subgroups, the adsorption isotherms were fitted with the Langmuir model followed by the Freundlich, Sips, Toth, and Liu models. The Dubinin-Radushkevich and Redlich-Peterson models were also used for fitting the adsorption isotherms of caffeine in the subgroups of aluminosilicate minerals and organic-inorganic composites.

4.2. Adsorption of Caffeine-Like Molecules. Adsorption of similarly sized molecules can be an indicative of a suitable material for caffeine removal (similar to caffeine such as pharmaceuticals, stimulants, and personal use products), as molecular size and pore distribution influence the adsorption process, particularly on activated carbons [49]. For example, caffeine and diclofenac both have spherical equivalent diameters of $6.9 \AA$ and $7.7 \AA$, respectively, and their adsorption in presence of powder carbonaceous

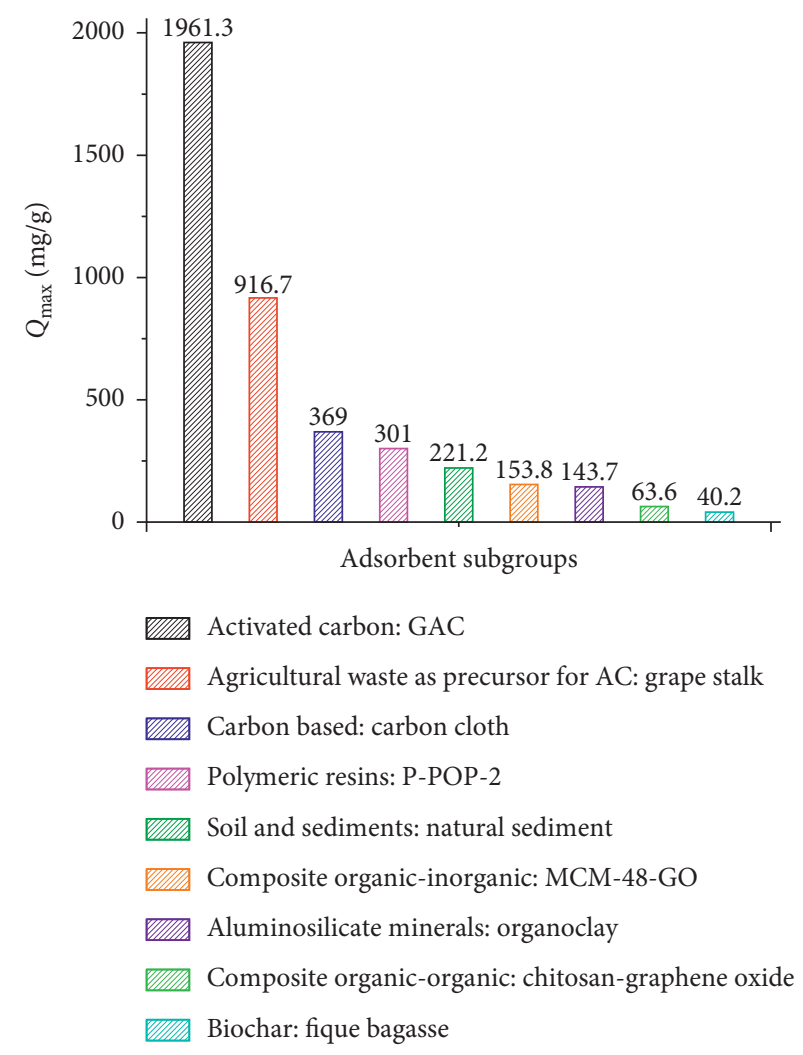

FIgURE 5: Maximum caffeine adsorption capacity per adsorbent subgroup.

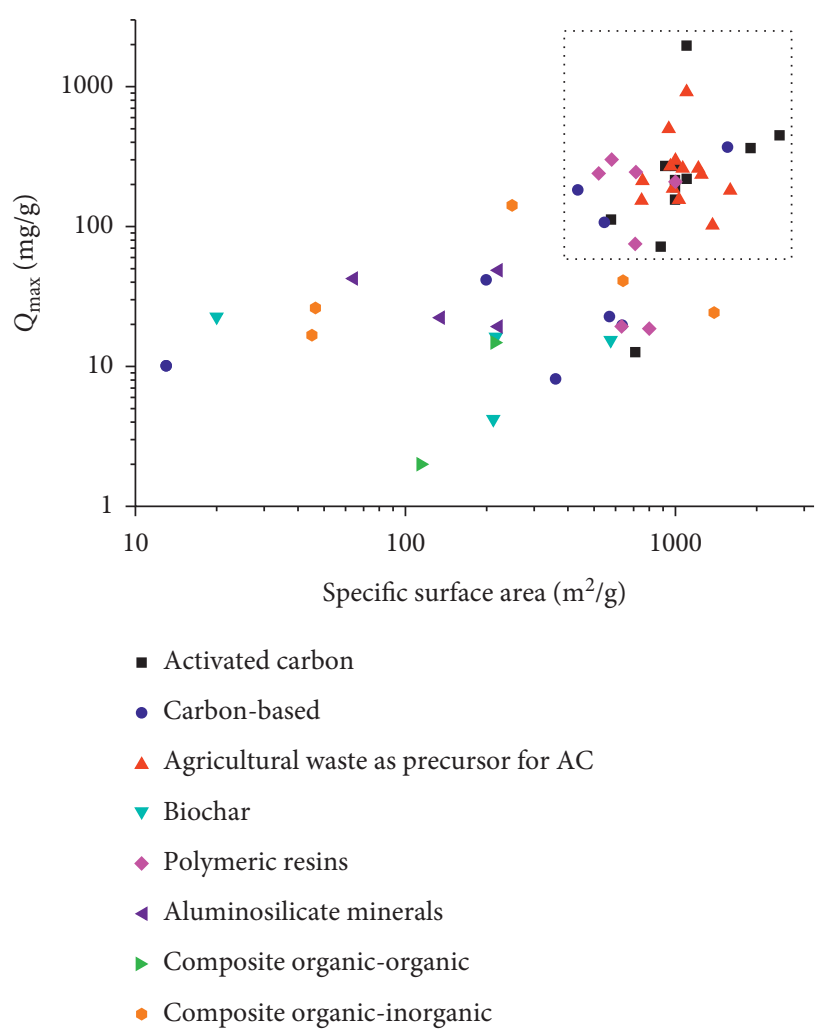

FIGURE 6: Relationship between the maximum adsorption capacity and specific surface area by adsorbent subgroups. 


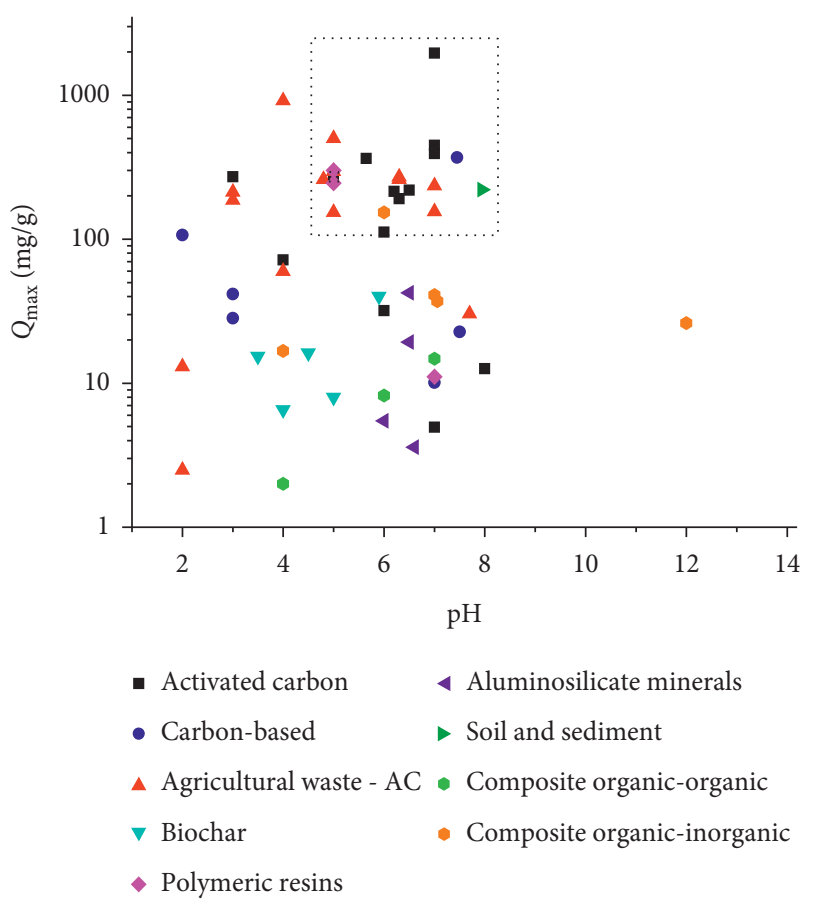

FIGURE 7: Relationship between the maximum adsorption capacity by adsorbent subgroups and $\mathrm{pH}$.

materials can be attributed to their volumes being considerably smaller than the pore size of such materials [72]. Sotelo et al. [72] studied the removal of caffeine and diclofenac as emerging contaminants with three powder carbonaceous materials: activated carbon (AC, $\left.S_{\mathrm{BET}}=997.0 \mathrm{~m}^{2} / \mathrm{g}, V_{\text {micro }}=0.260 \mathrm{~cm}^{3} / \mathrm{g}\right)$, multiwalled carbon nanotubes (MWNT, $S_{\mathrm{BET}}=162.2 \mathrm{~m}^{2} / \mathrm{g}, V_{\text {micro }}=0.016 \mathrm{~cm}^{3} / \mathrm{g}$ ), and carbon nanofibers $\left(\mathrm{CNF}, S_{\mathrm{BET}}=199.1 \mathrm{~m}^{2} / \mathrm{g}, V_{\text {micro }}=\right.$ $0.012 \mathrm{~cm}^{3} / \mathrm{g}$ ). Carbonaceous materials were effective for the removal of emerging contaminants since the size of these compounds is considerably smaller than the pore size of AC, MWNT, or CNF. $Q_{\max }$ values for compounds in ultrapure water on AC, MWNT, and CNF were 271.0, 41.6, and $28.3 \mathrm{mg} / \mathrm{g}$ for caffeine and $329.0,41.4$, and $29.9 \mathrm{mg} / \mathrm{g}$ for diclofenac, respectively.

In a subsequent study, Sotelo et al. [49] investigated the adsorption of caffeine and diclofenac by granular activated carbon F-400 $\left(S_{\text {BET }}=997 \mathrm{~m}^{2} / \mathrm{g}\right.$ and $\left.V_{\text {micro }}=0.26 \mathrm{~cm}^{3} / \mathrm{g}\right)$. The molecular size of caffeine is $0.98 \times 0.87 \mathrm{~nm}$ compared to that of diclofenac, $0.97 \times 0.96 \mathrm{~nm}$. In competitive adsorption, adsorption capacities for caffeine and diclofenac were 190.9 and $233.9 \mathrm{mg} / \mathrm{g}$, respectively. Both adsorption capacities decreased compared to the single adsorption system by $32.1 \%$ for caffeine and $29.1 \%$ for diclofenac. Caffeine and diclofenac molecules accessed similarly sized pores and directly competed for the same adsorption sites. Higher values of octanol-water partition coefficient of a diclofenac molecule might be responsible for the stronger affinity of the adsorbent surface.

Mailler et al. [152] explored the removal of 15 micropollutants (including pharmaceutical, stimulant, and personal use compounds) from wastewater treatment plant discharges using 4 types of activated carbons with different micro- and mesoporosity ratios. The highest average removal of the pollutants investigated was $52 \%$, which was achieved with $\mathrm{PB} 170^{\circledR}$ $\left(S_{\mathrm{BET}}=957 \mathrm{~m}^{2} / \mathrm{g}, \quad V_{\text {micro }+ \text { meso }}=0.5066 \mathrm{~cm}^{3} / \mathrm{g}\right), \quad$ an activated carbon with the highest specific surface area and volume of micro-mesopores. The lowest average removal (26\%) was obtained with PC $1000^{\circledR} \quad\left(S_{\mathrm{BET}}=458 \mathrm{~m}^{2} / \mathrm{g}, V_{\text {micro+meso }}=\right.$ $0.2435 \mathrm{~cm}^{3} / \mathrm{g}$ ), which is the activated carbon with the lowest specific surface area and volume of micro-mesopores. For the other two activated carbons (WP $235^{\circledR}$ and $\mathrm{W} 35^{\circledR}$ ) with similar pore volume $\left(0.4841\right.$ and $\left.0.4876 \mathrm{~cm}^{3} / \mathrm{g}\right)$, the average removal was $45 \%$. In conclusion, the removal of micropollutants is associated with chemical characteristics of the compounds and textural properties of the adsorbent material, being favored by adsorbents with high specific surface area and micro and mesoporous volume.

Gil et al. [74] studied the removal of six emerging contaminants from aqueous solutions using a commercial granular activated carbon as an adsorbent $\left(S_{\mathrm{BET}}=578 \mathrm{~m}^{2} / \mathrm{g}\right.$, $V_{\text {totalpore }}=0.564 \mathrm{~cm}^{3} / \mathrm{g}, \quad V_{\text {micro }}=0.206 \mathrm{~cm}^{3} / \mathrm{g}$ ). The $Q_{\max }$ calculated for salicylic acid, caffeine, diclofenac, and ibuprofen from the isotherm fitting to the Langmuir model were $33,88,64$, and $34 \mathrm{mg} / \mathrm{g}$, respectively. In conclusion, organic molecules used in this study had a similar chemical structure. Therefore, the behavior during the adsorption by the activated carbon will also be very similar. Finally, Zhang et al. [153] evaluated the performance of powdered activated carbon (PAC, $S_{\mathrm{BET}}=852.94 \mathrm{~m}^{2} / \mathrm{g}$ ) for removing 28 types of antibiotics from water. Results of the PAC adsorption experiments showed that the percentage of removal of 28 selected antibiotics ranged from 96.5 to $99.9 \%$ and $86.8-99.6 \%$ in deionized water and surface water, respectively.

4.3. Interaction of Caffeine with Adsorbents. The porous structure of the adsorbent material, energy heterogeneity, and surface chemical properties (presence of functional groups) are the main factors influencing the adsorption equilibrium [154]. Caffeine has a high dipole moment, and its positive charge of the nitrogen atom electrostatically interacts with any negatively polarized functional group [17]. The pKa of caffeine is 10.4, and the protonated form of this molecule in aqueous solution exists when $\mathrm{pH}<\mathrm{pKa}$ [41].

In carbonaceous adsorbents, such as activated carbon or graphene, the carbon surface has polar groups with hydrophilic behavior such as $-\mathrm{NH},-\mathrm{OH},-\mathrm{O}$, and $-\mathrm{COO}$. Therefore, the adsorption of caffeine can be attributed to dipole-dipole interactions, where $\pi$-electrons and 2-nitrophenol aromatic rings of caffeine interact with the $\pi$-aromatic electrons present on the adsorbent surface [17, 41, 84]. Beltrame et al. [54] explained caffeine adsorption as the result of $\pi-\pi$ interactions and the formation of hydrogen bonds between caffeine heterocyclic rings and the aromatic rings of activated carbon (from pineapple plant) in a $\mathrm{pH}$ range of 2-7.

The removal of caffeine when the $\mathrm{pH}$ is lower than the zero charge point of the adsorbent (PZC) has been explained by hydrogen bonding between the adsorbent and adsorbate, as the surface of the material has a predominantly positive 
charge density and caffeine would not be electrostatically attracted to it [72].

The adsorption of caffeine with noncarbon adsorbents has been focused on low-cost materials such as sediments, polymer resins, and aluminosilicates, whose application is favored by the chemical properties of caffeine (high $\mathrm{pKa}$ and dipole moment). In these materials, the interaction of caffeine with the adsorbate is attributed to $\mathrm{H}$-bonds, dipole-ion interactions, electrostatic interactions, and Van der Waals interactions [17, 40, 41, 155].

The adsorption of caffeine on inorganic surfaces of the natural sandy sediment occurs because caffeine is positively ionized at the experimental $\mathrm{pH}$ (7.94) and the sediment surface is negatively charged. Furthermore, the distribution coefficient $(\mathrm{Kd})$ of caffeine on the inorganic surface $(\mathrm{Kd}=17.58)$ is greater than that on organic matter $(\mathrm{Kd}=0.28)$, confirming that the interactions of caffeine with inorganic surfaces control its adsorption on the sediment $[41,53]$.

In aluminosilicates, adsorption is facilitated in the interlayer space, even more so when these types of adsorbents are modified by expanding the interlayer space with quaternary ammonium sales [32, 43]. However, caffeine was also removed in thermally modified bentonite at temperatures above $400^{\circ} \mathrm{C}$, i.e., when it has undergone a collapse, so that, in such case, the interaction of caffeine does not occur in the interlayer space but on the surface of the bentonite [130].

4.4. Regeneration and Reuse of Adsorbents. Although the adsorption capacity is an essential criterion in the selection of an adsorbent, its regeneration after use should be considered in a lifecycle analysis of the material, but only three publications out of the 133 selected included an analyzed reuse [68, 86, 97]. Similarly, in only one of the 45 manuscripts selected by Bachmann et al. [41] in their review on the removal of caffeine from aqueous media by adsorption, adsorbent regeneration tests were performed.

Batista et al. [97] used rapeseed activated carbons prepared by chemical activation with $\mathrm{K}_{2} \mathrm{CO}_{3}$ for caffeine adsorption. Temperatures of 400,500 , and $600^{\circ} \mathrm{C}$ under $\mathrm{N}_{2}$ flow were selected to carry out the regeneration assays. The thermal treatment at $400^{\circ} \mathrm{C}$ did not allow an effective regeneration of the activated carbon, and only $30 \%$ of the original adsorption capacity for caffeine was retained. For activated carbons regenerated at 500 or $600^{\circ} \mathrm{C}$, an almost complete recovery of the caffeine adsorption capacity was observed (>95\%), even after the second regeneration cycle. The $\mathrm{N}_{2}$ adsorption isotherms of the samples obtained after two exhaustion-regeneration cycles showed that at high regeneration temperatures $\left(500\right.$ and $\left.600^{\circ} \mathrm{C}\right)$, the volume of micropores available is higher. It is important to consider that activated carbons are regenerated ex situ by heating or steaming, which is a high energy-consuming process and can limit the reuse of the adsorbent [41, 94].

Multiwalled carbon nanotubes were used for the adsorption of diclofenac and caffeine. The adsorbent used was separated from the solution by filtration and treated with $0.1 \mathrm{M}$ $\mathrm{HCl}$ for $2 \mathrm{~h}$ to desorb the organic retained compounds. The solid was then separated from the acid solution by filtration, washed with deionized water, and dried in an oven at $60^{\circ} \mathrm{C}$ for $48 \mathrm{~h}$ before being reused in the adsorption experiments. The reusability of this adsorbent was studied, and it was found to maintain its adsorption capacity after one cycle of reuse. However, data only referred to diclofenac [86].

Discarded granular activated carbon from a drinking water treatment plant was used for the adsorption of different pharmaceutical compounds, specifically caffeine, ibuprofen, and diazepam. The results were very promising since the reused carbon adsorbed caffeine (initial concentration of $1.23 \mathrm{mg} / \mathrm{L}$, bed height of $10 \mathrm{~cm}$, and weight of $13.51 \mathrm{~g}$ ) and achieved a removal of about $40 \%$. The reused activated carbon achieved a better performance for pharmaceutical compounds elimination as powder after grinding (at a concentration of $0.5 \mathrm{~g} / \mathrm{L}$ ) than as granular carbon in column. Caffeine was removed in percentage higher than $90 \%$. Thus, future applications of used granular activated carbon, particularly in the framework of a circular economy, may be possible [68].

Abdel-Aziz et al. [156] synthesized bimetallic zero-valent iron/copper nanoparticles (FB-nZVFe/Cu), having used this material for caffeine adsorption. $\mathrm{FB}-\mathrm{nZVFe} / \mathrm{Cu}$ was used during five successive times for the adsorption of caffeine $(5 \mathrm{mg} / \mathrm{L})$. Between each adsorption cycle, $\mathrm{FB}-\mathrm{nZVFe} / \mathrm{Cu}$ was immediately collected from solution by centrifugation, washed with ethanol, and dried at $45 \mathrm{C}$, before being used for the next adsorption recycle. The caffeine removal was 82,78 , $83,83,70$, and $69 \%$ in the 1 st, $2 \mathrm{nd}, 3 \mathrm{rd}, 4$ th, and 5 th cycle of use, respectively. Although a decrease in the removal efficiency was found with each reuse cycle, the FB-nZVFe/Cu material offered a high potential to be repeatedly used for caffeine removal without a considerable decrease in its removal efficiency. This article was not included for the analysis of adsorbents since its publication occurred after the date established in the search strategy.

\section{Conclusions}

The systematic literature review of publications on caffeine adsorption indicates that it is a recent and developing research topic because caffeine is becoming an emerging contaminant found in different types of water (surface, drinking, and wastewater). Caffeine is listed, along with nicotine, paraxanthine, and cotinine, as an anthropogenic marker of contamination, hence the importance of researching on methods for its removal. Of the total number of publications analyzed, $91.7 \%$ are research articles, $93.8 \%$ are written in English, and $67.1 \%$ are concentrated in four journals: Science of the Total Environment, Chemosphere, Environmental Science, and Chemical Engineering Journal.

Adsorption is one of the most frequently used methods for the removal of emerging contaminants, including caffeine. Powdered activated carbon (PAC) and granular activated carbon (PAC) are the mainly studied adsorbents for removal of caffeine. Their wide use is associated with their high specific surface area (up to $2431 \mathrm{~m}^{2} / \mathrm{g}$ ) and high adsorption capacities (up to $1961.3 \mathrm{mg} / \mathrm{g}$ ).

The high cost of activated carbon and its difficult regeneration have led to the search for low-cost, widely available, and ecofriendly adsorbents. Materials obtained 
from agricultural biomass waste, polymeric resins, clay minerals, soil and sediments, and organic-inorganic compounds emerge as an alternative adsorbent for the removal of caffeine. However, high doses (100 to $40000 \mathrm{mg} / \mathrm{L}$ ) are required to achieve high removal of caffeine.

In $49 \%$ of the investigations analyzed in this review, the adsorption isotherms for caffeine fit into the Langmuir model, which assumes that adsorption takes place in a monolayer and that there is homogeneity on the surface of the adsorbent.

The adsorption capacity of caffeine depends on the properties of the adsorbent and other factors such as $\mathrm{pH}$, adsorbate concentration, agitation speed, and contact time. Removal of caffeine increased with increasing adsorbent dose (or adsorbent amount) since the number of adsorption sites is greater. However, the capacity, in some cases, decreased with an increasing dose. This is because of the aggregation of particles, which leads to a decrease in active sites for adsorption. Determining the adsorbent dose is a useful factor in predicting the cost of the process per unit of solution to be treated.

\section{Abbreviations}

AC:

Activated carbon

C18: Column that uses octadecylsilane as the stationary phase

CFN: $\quad$ Carbon nanofibers

D101: Macroporous resin of nonpolar styrene-codivinylbenzene copolymer groups

DEGMA: Ethylene glycol dimethacrylate

ECs: $\quad$ Emerging contaminants

F-400: $\quad$ Granular activated carbon (Filtrasorb 400)

FB-nZVFe/ Bimetallic zero-valent iron/copper

$\mathrm{Cu}: \quad$ nanoparticles

GAC: $\quad$ Granular activated carbon

GO: $\quad$ Graphene oxide

GS18: $\quad$ Styrene-divinyl benzene

IM: $\quad$ Isotherm model

Kd: $\quad$ Distribution coefficient

Kow: Octanol-water partition coefficient

LDH: $\quad$ Layered double hydroxide

MAR: $\quad$ Macroporous adsorption resin

MCM-48: Class of ordered mesoporous silica with cubic symmetry

MG 1050: Granular activated carbon (mesoporous) from Chiemivall-Spain

MIP: $\quad$ Molecular imprinted polymer

MWNT: Multiwalled carbon nanotubes

NIPAAm: N-isopropylacrylamide

Oasis ${ }^{\circledR} \quad$ Universal polymeric reversed-phase sorbent

HLB: cartridge (water corporation)

PAC: $\quad$ Powdered activated carbon

PB 170 ${ }^{\circledR}$ : Activated carbon commercialized by DaCarb ${ }^{\circledR}$ (France)

PC $1000^{\circledR}$ : $\quad$ Activated carbon commercialized by DaCarb ${ }^{\circledR}$ (France)

pKa: $\quad-\operatorname{logKa}, \mathrm{Ka}$ acid dissociation constant

P-POP: Phosphate-based porous organic polymers
P-POP-1: P-POP, diphenyl phosphate and 1,1,2,2-

tetraphenylethylene as precursor

P-POP-2: P-POP, diphenyl phosphate and 1,3,5-

triphenylbenzene as precursors

PSt: $\quad$ Polystyrene microbeads

PVP: $\quad$ N-vinyl-2-pyrrolidinone

PZC: $\quad$ Point zero charge

$Q_{\max }$ : $\quad$ Maximum adsorption capacity

SBA-15: $\quad$ Class of ordered mesoporous silica, Santa Barbara Amorphous-15

SR 5500: $\quad$ Epoxy resin 5500 (Sicomin Epoxy Systems)

$S_{\text {BET }}$ Specific BET surface, BET (Brunauer, Emmett, and Teller)

SSA: $\quad$ Specific surface area

TAIC: Triallyl isocyanurate

UiO-66: Zirconium-based MOF

WP 235 ${ }^{\circledR}$ : Activated carbon commercialized by Chemviron ${ }^{\circledR}$ (Belgium)

W 35 ${ }^{\circledR}$ : $\quad$ Activated carbon commercialized by Norit $^{\circledR}$ (Netherlands)

XAD: $\quad$ Macroporous resin with a styrene-divinyl benzene structure and hydroxyl functional groups

XAD-7: Amberlite, matrix: aliphatic carboxylic acid polymer

XDA-200: Hyper-crosslinked polystyrene macroporous.

\section{Data Availability}

All data used to support the findings of this study are included within the article.

\section{Conflicts of Interest}

The authors declare that there are no conflicts of interest regarding the publication of this paper.

\section{Acknowledgments}

The authors gratefully acknowledge the financial support of Universidad Nacional de Colombia Sede Manizales (Project DIMA-UNAL 50752) and MinCiencias through the "Announcement for National Doctorates 785". The authors also thank the Unit of Strategic Information Analysis-Library Section, Universidad Nacional de Colombia Sede Manizales, for its valuable collaboration in the preparation of this brief bibliometric analysis.

\section{References}

[1] M. Taheran, M. Naghdi, S. K. Brar, M. Verma, and R. Y. Surampalli, "Emerging contaminants: here today, there tomorrow!" Environmental Nanotechnology, Monitoring \& Management, vol. 10, pp. 122-126, 2018.

[2] R. Naidu, J. Jit, B. Kennedy, and V. Arias, "Emerging contaminant uncertainties and policy: the chicken or the egg conundrum," Chemosphere, vol. 154, pp. 385-390, 2016.

[3] M. Stuart, D. Lapworth, E. Crane, and A. Hart, "Review of risk from potential emerging contaminants in UK 
groundwater," Science of the Total Environment, vol. 416, pp. 1-21, 2012.

[4] D. J. Lapworth, N. Baran, M. E. Stuart, and R. S. Ward, "Emerging organic contaminants in groundwater: a review of sources, fate and occurrence," Environmental Pollution, vol. 163, pp. 287-303, 2012.

[5] C. Postigo and D. Barceló, "Synthetic organic compounds and their transformation products in groundwater: occurrence, fate and mitigation," Science of the Total Environment, vol. 503-504, pp. 32-47, 2015.

[6] I. J. Buerge, M. Kahle, H.-R. Buser, M. D. Müller, and T. Poiger, "Nicotine derivatives in wastewater and surface waters: application as chemical markers for domestic wastewater," Environmental Science \& Technology, vol. 42, no. 17, pp. 6354-6360, 2008.

[7] M. S. Fram and K. Belitz, "Occurrence and concentrations of pharmaceutical compounds in groundwater used for public drinking-water supply in California," Science of the Total Environment, vol. 409, no. 18, pp. 3409-3417, 2011.

[8] J. M. Philip, U. K. Aravind, and C. T. Aravindakumar, "Emerging contaminants in Indian environmental matrices a review," Chemosphere, vol. 190, pp. 307-326, 2018.

[9] F. S. Miranda and B. Kenneth, "Occurrence and concentrations of pharmaceutical compounds in groundwater used for public drinking-water supply in California," Science of the Total Environment, vol. 409, no. 18, pp. 3409-3417, 2011.

[10] A. Gogoi, P. Mazumder, V. K. Tyagi, G. G. Tushara Chaminda, A. K. An, and M. Kumar, "Occurrence and fate of emerging contaminants in water environment: a review," Groundwater for Sustainable Development, vol. 6, pp. 169$180,2018$.

[11] Y. H. Huang, L. Dsikowitzky, F. Yang et al., "Emerging contaminants in municipal wastewaters and their relevance for the surface water contamination in the tropical coastal city Haikou, China," Estuarine, Coastal and Shelf Science, vol. 235, Article ID 106611, 2020.

[12] T. Heberer, "Tracking persistent pharmaceutical residues from municipal sewage to drinking water," Journal of $\mathrm{Hy}$ drology, vol. 266, no. 3-4, pp. 175-189, 2002.

[13] I. J. Buerge, T. Poiger, and H.-R. Buser, "Caffeine, an anthropogenic marker for wastewater contamination of surface waters," Environmental Science \& Technology, vol. 37, no. 4, pp. 691-700, 2003.

[14] S. González-Alonso, L. M. Merino, S. Esteban et al., "Occurrence of pharmaceutical, recreational and psychotropic drug residues in surface water on the northern Antarctic Peninsula region," Environmental Pollution, vol. 229, pp. 241-254, 2017.

[15] T. Lin, S. Yu, and W. Chen, "Occurrence, removal and risk assessment of pharmaceutical and personal care products (PPCPs) in an advanced drinking water treatment plant (ADWTP) around Taihu Lake in China," Chemosphere, vol. 152, pp. 1-9, 2016.

[16] S. Castiglioni, E. Davoli, F. Riva et al., "Data on occurrence and fate of emerging contaminants in a urbanised area," Data in Brief, vol. 17, pp. 533-543, 2018.

[17] C. Rigueto, M. Nazari, C. De Souza et al., "Alternative techniques for caffeine removal from wastewater: an overview of opportunities and challenges," Journal of Water Process Engineering, vol. 35, Article ID 101231, 2020.

[18] W. Srisuphan and M. B. Bracken, "Caffeine consumption during pregnancy and association with late spontaneous abortion," American Journal of Obstetrics and Gynecology, vol. 154, no. 1, pp. 14-20, 1986.
[19] P. R. Gardinali and X. Zhao, "Trace determination of caffeine in surface water samples by liquid chromatography-atmospheric pressure chemical ionization-mass spectrometry (LC-APCI-MS)," Environment International, vol. 28, no. 6, pp. 521-528, 2002.

[20] T. Bruton, A. Alboloushi, B. De La Garza, B.-O. Kim, and R. U. Halden, "Fate of caffeine in the environment and ecotoxicological considerations, ACS symposium series," in Contaminants of Emerging Concern in the Environment: Ecological and Human Health Considerations, R. U. Halden, Ed., American Chemical Society, Washington, DC, USA, pp. 257-273, 2010.

[21] L. Tavagnacco, S. Di Fonzo, F. Masciovecchio, J. W. Brady, and A. Cesàro, "Stacking of purines in water: the role of dipolar interactions in caffeine," Physical Chemistry Chemical Physics, vol. 18, no. 19, pp. 13478-13486, 2016.

[22] K. Yamamoto, T. Shiono, Y. Matsui et al., "Interaction of caffeine with montmorillonite," Particulate Science and Technology, vol. 37, no. 3, pp. 1-8, 2019.

[23] J. Garcia-Ivars, M.-I. Iborra-Clar, M. Massella, C. CarbonellAlcaina, and M.-I. Alcaina-Miranda, "Removal of pharmaceutically active compounds by using low-pressure membrane processes," Desalination and Water Treatment, vol. 69, pp. 252-260, 2017.

[24] K. P. M. Licona, L. R. d. O. Geaquinto, J. V. Nicolini et al., "Assessing potential of nanofiltration and reverse osmosis for removal of toxic pharmaceuticals from water," Journal of Water Process Engineering, vol. 25, pp. 195-204, 2018.

[25] E. Mena, A. Rey, and F. J. Beltrán, " $\mathrm{TiO}_{2}$ photocatalytic oxidation of a mixture of emerging contaminants: a kinetic study independent of radiation absorption based on the direct-indirect model," Chemical Engineering Journal, vol. 339, pp. 369-380, 2018.

[26] P. M. Thomas and G. D. Foster, "Tracking acidic pharmaceuticals, caffeine, and triclosan through the wastewater treatment process," Environmental Toxicology and Chemistry, vol. 24, no. 1, pp. 25-30, 2005.

[27] L. Li, L. Gong, Y.-X. Wang et al., "Removal of halogenated emerging contaminants from water by nitrogen-doped graphene decorated with palladium nanoparticles: experimental investigation and theoretical analysis," Water Research, vol. 98, pp. 235-241, 2016.

[28] A. V. Dordio, S. Miranda, and A. J. P. Carvalho, "Mechanisms of removal of three widespread pharmaceuticals by two clay materials," Journal of Hazardous Materials, vol. 323, pp. 575-583, 2017.

[29] C. Hurtado, S. Trapp, and J. M. Bayona, "Inverse modeling of the biodegradation of emerging organic contaminants in the soil-plant system," Chemosphere, vol. 156, pp. 236-244, 2016.

[30] J. L. Sotelo, A. Rodríguez, S. Álvarez, and J. García, "Removal of caffeine and diclofenac on activated carbon in fixed bed column," Chemical Engineering Research and Design, vol. 90, no. 7, pp. 967-974, 2012.

[31] R. Zhu, Q. Chen, Q. Zhou, Y. Xi, J. Zhu, and H. He, “Adsorbents based on montmorillonite for contaminant removal from water: a review," Applied Clay Science, vol. 123, pp. 239-258, 2016.

[32] L. Marçal, E. H. De Faria, E. J. Nassar et al., "Organically modified saponites: SAXS study of swelling and application in caffeine removal," ACS Applied Materials \& Interfaces, vol. 7, no. 20, pp. 10853-10862, 2015.

[33] S. Álvarez-Torrellas, A. Rodríguez, G. Ovejero, J. M. Gómez, and J. García, "Removal of caffeine from pharmaceutical wastewater by adsorption: influence of NOM, textural and 
chemical properties of the adsorbent," Environmental Technology, vol. 37, no. 13, pp. 1618-1630, 2016.

[34] S. Pandey, "A comprehensive review on recent developments in bentonite-based materials used as adsorbents for wastewater treatment," Journal of Molecular Liquids, vol. 241, pp. 1091-1113, 2017.

[35] C. J. Geankoplis, A. A. Hersel, and D. H. Lepek, Transport Processes and Separation Process Principles, Prentice Hall, Boston, MA, USA, 2018.

[36] G. Mezohegyi, F. P. van der Zee, J. Font, A. Fortuny, and A. Fabregat, "Towards advanced aqueous dye removal processes: a short review on the versatile role of activated carbon," Journal of Environmental Management, vol. 102, pp. 148-164, 2012.

[37] M. Salleh, D. Mahmoud, W. Karim et al., "Cationic and anionic dye adsorption by agricultural solid wastes: a comprehensive review," Desalination, vol. 280, no. 1-3, pp. 1-13, 2011.

[38] R. G. Saratale, G. D. Saratale, J. S. Chang, and S. P. Govindwar, "Bacterial decolorization and degradation of azo dyes: a review," Journal of the Taiwan Institute of Chemical Engineers, vol. 42, no. 1, pp. 138-157, 2011.

[39] G. L. Dotto, S. K. Sharma, and L. A. A. Pinto, "Biosorption of organic dyes: research opportunities and challenges," in Green Chemistry for Dyes Removal from Waste Water: Research Trends and Applications, S. K. Sharma, Ed., Scrivener Publishing LLC, New Jersey, NJ, USA, pp. 295-329, 2015.

[40] I. Anastopoulos, I. Pashalidis, A. G. Orfanos et al., "Removal of caffeine, nicotine and amoxicillin from (waste) waters by various adsorbents. A review," Journal of Environmental Management, vol. 261, Article ID 110236, 2020.

[41] S. A. L. Bachmann, T. Calvete, and L. A. Féris, "Caffeine removal from aqueous media by adsorption: an overview of adsorbents evolution and the kinetic, equilibrium and thermodynamic studies," Science of the Total Environment, vol. 767, Article ID 144229, 2020.

[42] W. A. Cabrera-Lafaurie, F. R. Román, and A. J. HernándezMaldonado, "Single and multi-component adsorption of salicylic acid, clofibric acid, carbamazepine and caffeine from water onto transition metal modified and partially calcined inorganic-organic pillared clay fixed beds," Journal of Hazardous Materials, vol. 282, pp. 174-182, 2015.

[43] T. Okada, J. Oguchi, K.-I. Yamamoto, T. Shiono, M. Fujita, and T. Iiyama, "Organoclays in water cause expansion that facilitates caffeine adsorption," Langmuir, vol. 31, no. 1, pp. 180-187, 2015.

[44] J.-M. Chern, W.-F. Lee, and M.-Y. Hsieh, "Absorption isotherm of caffeine and release kinetics from swollen NIPAAm hydrogels: experiments and modeling," Industrial \& Engineering Chemistry Research, vol. 43, no. 19, pp. 6150-6156, 2004.

[45] N. Bakkalbasi, K. Bauer, J. Glover et al., "Three options for citation tracking: Google scholar, Scopus and Web of science," BioMed Research International, vol. 3, no. 7, pp. 1-8, 2006.

[46] U. R. de Oliveira, L. S. Espindola, I. R. Da Silva, I. N. da Silva, and H. M. Rocha, "A systematic literature review on green supply chain management: research implications and future perspectives," Journal of Cleaner Production, vol. 187, pp. 537-561, 2018.

[47] S.-W. Nam, D.-J. Choi, S.-K. Kim, N. Her, and K.-D. Zoh, "Adsorption characteristics of selected hydrophilic and hydrophobic micropollutants in water using activated carbon," Journal of Hazardous Materials, vol. 270, pp. 144-152, 2014.

[48] L. A. Al-Khateeb, S. Almotiry, and M. A. Salam, "Adsorption of pharmaceutical pollutants onto graphene nanoplatelets," Chemical Engineering Journal, vol. 248, pp. 191-199, 2014.

[49] J. L. Sotelo, G. Ovejero, A. Rodríguez, S. Álvarez, J. Galán, and J. García, "Competitive adsorption studies of caffeine and diclofenac aqueous solutions by activated carbon," Chemical Engineering Journal, vol. 240, pp. 443-453, 2014.

[50] A. Y. Lin, C. A. Lin, H. H. Tung, and N. S. Chary, "Potential for biodegradation and sorption of acetaminophen, caffeine, propranolol and acebutolol in lab-scale aqueous environments," Journal of Hazardous Materials, vol. 183, no. 1-3, pp. 242-250, 2010.

[51] S. Álvarez, R. García, N. Escalona et al., "Chemical-activated carbons from peach stones for the adsorption of emerging contaminants in aqueous solutions," International Journal of Chemical Engineering, vol. 279, pp. 788-798, 2015.

[52] S. Álvarez, R. S. Ribeiro, H. T. Gomes, J. L. Sotelo, and J. García, "Synthesis of carbon xerogels and their application in adsorption studies of caffeine and diclofenac as emerging contaminants," Chemical Engineering Research and Design, vol. 95, pp. 229-238, 2015.

[53] V. Martínez-Hernández, R. Meffe, S. Herrera, E. Arranz, and I. de Bustamante, "Sorption/desorption of non-hydrophobic and ionisable pharmaceutical and personal care products from reclaimed water onto/from a natural sediment," Science of the Total Environment, vol. 472, pp. 273-281, 2014.

[54] K. K. Beltrame, A. L. Cazetta, P. S. C. de Souza, L. Spessato, T. L. Silva, and V. C. Almeida, "Adsorption of caffeine on mesoporous activated carbon fibers prepared from pineapple plant leaves," Ecotoxicology and Environmental Safety, vol. 147, pp. 64-71, 2018.

[55] A. S. Mestre, R. A. Pires, I. Aroso et al., "Activated carbons prepared from industrial pre-treated cork: sustainable adsorbents for pharmaceutical compounds removal," Chemical Engineering Journal, vol. 253, pp. 408-417, 2014.

[56] J. Akhtar, N. A. S. Amin, and K. Shahzad, "A review on removal of pharmaceuticals from water by adsorption," Desalination and Water Treatment, vol. 57, no. 27, pp. 12842-12860, 2016.

[57] M. Inagaki and J. M. D. Tascón, "Chapter 2 pore formation and control in carbon materials, interface science and technology," in Activated Carbon Surfaces in Environmental Remediation, pp. 49-105, Elsevier, New York, NY, USA, 2006.

[58] M. A. Dutt, M. A. Hanif, F. Nadeem et al., "A review of advances in engineered composite materials popular for wastewater treatment," Journal of Environmental Chemical Engineering, vol. 8, no. 5, Article ID 104073, 2020.

[59] W. A. Cabrera-Lafaurie, F. R. Román, and A. J. HernándezMaldonado, "Transition metal modified and partially calcined inorganic-organic pillared clays for the adsorption of salicylic acid, clofibric acid, carbamazepine, and caffeine from water," Journal of Colloid and Interface Science, vol. 386, no. 1, pp. 381-391, 2012.

[60] S. Ravi, Y. Choi, and J. K. Choe, "Novel phenyl-phosphatebased porous organic polymers for removal of pharmaceutical contaminants in water," International Journal of Chemical Engineering, vol. 379, Article ID 122290, 2020.

[61] S. F. Azha, L. Sellaoui, E. H. Yee, A. Bonilla-Petriciolet, A. Ben Lamine, and S. Ismail, "Iron-modified composite adsorbent coating for azo dye removal and its regeneration by photo-Fenton process: synthesis, characterization and 
adsorption mechanism interpretation," Chemical Engineering Journal, vol. 361, pp. 31-40, 2019.

[62] M. S. Shamsudin, S. F. Azha, M. Shahadat et al., "Cellulose/ bentonite-zeolite composite adsorbent material coating for treatment of N-based antiseptic cationic dye from water," Journal of Water Process Engineering, vol. 29, Article ID 100764, 2019.

[63] J. Liu, Y. Chen, T. Han et al., “A biomimetic $\mathrm{SiO}_{2} @$ chitosan composite as highly-efficient adsorbent for removing heavy metal ions in drinking water," Chemosphere, vol. 214, pp. 738-742, 2019.

[64] M. Rajamani and K. Rajendrakumar, "Chitosan-boehmite desiccant composite as a promising adsorbent towards heavy metal removal," Journal of Environmental Management, vol. 244, pp. 257-264, 2019.

[65] A. C. Fröhlich, E. L. Foletto, and G. L. Dotto, "Preparation and characterization of $\mathrm{NiFe}_{2} \mathrm{O}_{4}$ /activated carbon composite as potential magnetic adsorbent for removal of ibuprofen and ketoprofen pharmaceuticals from aqueous solutions," Journal of Cleaner Production, vol. 229, pp. 828-837, 2019.

[66] Y. Liu, R. Wang, J. Bai et al., "Non-covalent self-assembly of multi-target polystyrene composite adsorbent with highly efficient $\mathrm{Cu}$ (II) ion removal capability," Colloids and Surfaces A: Physicochemical and Engineering Aspects, vol. 577, pp. 674-682, 2019.

[67] Ç. Sarici-Özdemir and Y. Önal, "Study to observe the applicability of the adsorption isotherms used for the adsorption of medicine organics onto activated carbon," Particulate Science and Technology, vol. 36, no. 2, pp. 254261, 2018.

[68] M. J. Luján, M. I. Iborra, J. A. Mendoza et al., "Pharmaceutical compounds removal by adsorption with commercial and reused carbon coming from a drinking water treatment plant," Journal of Cleaner Production, vol. 238, Article ID 117866, 2019.

[69] A. S. Mestre, E. Tyszko, M. A. Andrade, M. Galhetas, C. Freire, and A. P. Carvalho, "Sustainable activated carbons prepared from a sucrose-derived hydrochar: remarkable adsorbents for pharmaceutical compounds," RSC Advances, vol. 5, no. 25, pp. 19696-19707, 2015.

[70] Z. Huang, B. Gong, C.-P. Huang et al., "Performance evaluation of integrated adsorption-nanofiltration system for emerging compounds removal: exemplified by caffeine, diclofenac and octylphenol," Journal of Environmental Management, vol. 231, pp. 121-128, 2019.

[71] A. S. Mestre, S. C. R. Marques, and A. P. Carvalho, "Effect of the alcohol cosolvent in the removal of caffeine by activated carbons," Industrial \& Engineering Chemistry Research, vol. 51, no. 29, pp. 9850-9857, 2012.

[72] J. L. Sotelo, A. R. Rodríguez, M. M. Mateos, S. D. Hernández, S. A. Torrellas, and J. G. Rodríguez, "Adsorption of pharmaceutical compounds and an endocrine disruptor from aqueous solutions by carbon materials," Journal of Environmental Science and Health, Part B, vol. 47, no. 7, pp. 640-652, 2012.

[73] S. Álvarez-Torrellas, J. L. Sotelo, A. Rodríguez, G. Ovejero, and J. García, "Influence of the natural organic matter in the removal of caffeine from water by fixed-bed column adsorption," International Journal of Environmental Science and Technology, vol. 14, no. 4, pp. 833-840, 2017.

[74] A. Gil, N. Taoufik, A. M. García, and S. A. Korili, "Comparative removal of emerging contaminants from aqueous solution by adsorption on an activated carbon," Environmental Technology, vol. 40, no. 23, pp. 3017-3030, 2019.
[75] H. Kaur, A. Bansiwal, G. Hippargi, and G. R. Pophali, "Effect of hydrophobicity of pharmaceuticals and personal care products for adsorption on activated carbon: adsorption isotherms, kinetics and mechanism," Environmental Science and Pollution Research, vol. 25, no. 21, pp. 20473-20485, 2018.

[76] L. Luiza François, N. Krummenauer Haro, and L. Amaral Féris, "Caffeine removal by adsorption on activated carbon," Scientia Cum Industria, vol. 4, no. 2, pp. 64-68, 2016.

[77] J. L. Acero, F. Javier Benitez, F. J. Real, and F. Teva, "Coupling of adsorption, coagulation, and ultrafiltration processes for the removal of emerging contaminants in a secondary effluent," Chemical Engineering Journal, vol. 210, pp. 1-8, 2012.

[78] E. H. d. S. Carvalho, R. M. F. Cuba, and F. J. C. Teran, "Caffeine removal by activated carbon from coffee grounds with alternative activation in aluminum capsules," Periódico Tchê Química, vol. 16, no. 31, pp. 84-88, 2019.

[79] S. R. Yanala, "Use of biochar to produce reclaimed water for irrigation reuse purposes," Chemosphere, vol. 251, Article ID 126403, 2020.

[80] K. M. Lompe, S. Vo Duy, S. Peldszus, S. Sauvé, and B. Barbeau, "Removal of micropollutants by fresh and colonized magnetic powdered activated carbon," Journal of Hazardous Materials, vol. 360, pp. 349-355, 2018.

[81] S. Jamil, P. Loganathan, A. Listowski, J. Kandasamy, C. Khourshed, and S. Vigneswaran, "Simultaneous removal of natural organic matter and micro-organic pollutants from reverse osmosis concentrate using granular activated carbon," Water Research, vol. 155, pp. 106-114, 2019.

[82] Y. Jin, D.-K. Choi, and K. H. Row, "Adsorption isotherms of caffeine on molecular imprinted polymer," Korean Journal of Chemical Engineering, vol. 25, no. 4, pp. 816-818, 2008.

[83] Y. Wang, Q. Yang, J. Dong, and H. Huang, "Competitive adsorption of PPCP and humic substances by carbon nanotube membranes: effects of coagulation and PPCP properties," Science of the Total Environment, vol. 619-620, pp. 352-359, 2018.

[84] G. C. C. Yang and P.-L. Tang, "Removal of phthalates and pharmaceuticals from municipal wastewater by graphene adsorption process," Water Science and Technology, vol. 73, no. 9, pp. 2268-2274, 2016.

[85] S. Masson, C. Vaulot, L. Reinert, S. Guittonneau, R. Gadiou, and L. Duclaux, "Thermodynamic study of seven micropollutants adsorption onto an activated carbon cloth: Van't Hoff method, calorimetry, and COSMO-RS simulations," Environmental Science and Pollution Research, vol. 24, no. 11, pp. 10005-10017, 2017.

[86] A. Gil, L. Santamaría, and S. A. Korili, "Removal of caffeine and diclofenac from aqueous solution by adsorption on multiwalled carbon nanotubes," Colloid and Interface Science Communications, vol. 22, pp. 25-28, 2018.

[87] M. Ptaszkowska-Koniarz, J. Goscianska, and R. Pietrzak, "Synthesis of carbon xerogels modified with amine groups and copper for efficient adsorption of caffeine," Chemical Engineering Journal, vol. 345, pp. 13-21, 2018.

[88] J. i. Hayashi, T. Horikawa, I. Takeda, K. Muroyama, and F. Nasir Ani, "Preparing activated carbon from various nutshells by chemical activation with $\mathrm{K}_{2} \mathrm{CO}_{3}$," Carbon, vol. 40, no. 13, pp. 2381-2386, 2002.

[89] K. Okada, N. Yamamoto, Y. Kameshima, and A. Yasumori, "Porous properties of activated carbons from waste newspaper prepared by chemical and physical activation," Journal of Colloid and Interface Science, vol. 262, no. 1, pp. 179-193, 2003. 
[90] M. A. Yahya, Z. Al-Qodah, and C. W. Z. Ngah, "Agricultural bio-waste materials as potential sustainable precursors used for activated carbon production: a review," Renewable and Sustainable Energy Reviews, vol. 46, pp. 218-235, 2015.

[91] M. Galhetas, A. S. Mestre, M. L. Pinto, I. Gulyurtlu, H. Lopes, and A. P. Carvalho, "Chars from gasification of coal and pine activated with $\mathrm{K}_{2} \mathrm{CO}_{3}$ : acetaminophen and caffeine adsorption from aqueous solutions," Journal of Colloid and Interface Science, vol. 433, pp. 94-103, 2014.

[92] R. Portinho, O. Zanella, and L. A. Féris, "Grape stalk application for caffeine removal through adsorption," Journal of Environmental Management, vol. 202, pp. 178-187, 2017.

[93] L. L. A. Melo, A. H. Ide, J. L. S. Duarte et al., "Caffeine removal using Elaeis guineensis activated carbon: adsorption and RSM studies," Environmental Science and Pollution Research, vol. 27, no. 21, pp. 27048-27060, 2020.

[94] O. M. Couto, I. Matos, I. M. Da Fonseca, P. A. Arroyo, E. A. da Silva, and M. A. S. D. de Barros, "Effect of solution $\mathrm{pH}$ and influence of water hardness on caffeine adsorption onto activated carbons," The Canadian Journal of Chemical Engineering, vol. 93, no. 1, pp. 68-77, 2015.

[95] M. R. Cunha, E. C. Lima, N. F. G. M. Cimirro et al., "Conversion of Eragrostis plana Nees leaves to activated carbon by microwave-assisted pyrolysis for the removal of organic emerging contaminants from aqueous solutions," Environmental Science and Pollution Research, vol. 25, no. 23, pp. 23315-23327, 2018.

[96] M. Danish, J. Birnbach, M. Ibrahim et al., "Scavenging of caffeine from aqueous medium through optimized $\mathrm{H}_{3} \mathrm{PO}_{4}$ activated Acacia mangium wood activated carbon: statistical data of optimization," Data in Brief, vol. 28, Article ID 105045, 2020.

[97] M. K. S. Batista, A. S. Mestre, I. Matos, I. M. Fonseca, and A. P. Carvalho, "Biodiesel production waste as promising biomass precursor of reusable activated carbons for caffeine removal," RSC Advances, vol. 6, no. 51, pp. 45419-45427, 2016.

[98] O. Oginni, K. Singh, G. Oporto et al., "Effect of one-step and two-step $\mathrm{H}_{3} \mathrm{PO}_{4}$ activation on activated carbon characteristics," Bioresource Technology, vol. 8, Article ID 100307, 2019.

[99] I. Anastopoulos and I. Pashalidis, "The application of oxidized carbon derived from Luffa cylindrica for caffeine removal. Equilibrium, thermodynamic, kinetic and mechanistic analysis," Journal of Molecular Liquids, vol. 296, Article ID 112078, 2019.

[100] M. Danish, "Application of date stone activated carbon for the removal of caffeine molecules from water," Materials Today: Proceedings, vol. 31, pp. 18-22, 2020.

[101] E. Chelangat, F. Orata, D. Lilechi et al., "Adsorption of caffeine and ciprofloxacin onto pyrolitically derived water hyacinth biochar: isothermal, kinetic and thermodynamic studies," Journal of Chemical \& Engineering Data, vol. 10, pp. 185-194, 2016.

[102] S. Keerthanan, S. M. Rajapaksha, L. Trakal, and M Vithanage, "Caffeine removal by Gliricidia sepium biochar: influence of pyrolysis temperature and physicochemical properties," Environmental Research, vol. 189, Article ID 109865, 2020.

[103] A. U. Rajapaksha, M. Vithanage, M. Zhang et al., "Pyrolysis condition affected sulfamethazine sorption by tea waste biochars," Bioresource Technology, vol. 166, pp. 303-308, 2014.

[104] A. U. Rajapaksha, M. Vithanage, M. Ahmad et al., "Enhanced sulfamethazine removal by steam-activated invasive plant- derived biochar," Journal of Hazardous Materials, vol. 290, pp. 43-50, 2015.

[105] S. H. Kong, S. S. Lam, P. N. Y. Yek et al., "Self-purging microwave pyrolysis: an innovative approach to convert oil palm shell into carbon-rich biochar for methylene blue adsorption," Journal of Chemical Technology \& Biotechnology, vol. 94, no. 5, pp. 1397-1405, 2019.

[106] Q. Shen, Z. Wang, Q. Yu et al., "Removal of tetracycline from an aqueous solution using manganese dioxide modified biochar derived from Chinese herbal medicine residues," Environmental Research, vol. 183, Article ID 109195, 2020.

[107] Y. Correa, L. Giraldo, and J. Moreno, "Dataset for effect of $\mathrm{pH}$ on caffeine and diclofenac adsorption from aqueous solution onto fique bagasse biochars," Data in Brief, vol. 25, Article ID 104111, 2019.

[108] S. Román, B. Ledesma, A. Álvarez et al., "Towards sustainable micro-pollutants' removal from wastewaters: caffeine solubility, self-diffusion and adsorption studies from aqueous solutions into hydrochars," Molecular Physics, vol. 116, no. 15-16, pp. 2129-2141, 2018.

[109] S. Keerthanan, A. Bhatnagar, K. Mahatantila et al., "Engineered tea-waste biochar for the removal of caffeine, a model compound in pharmaceuticals and personal care products (PPCPs), from aqueous media," Environmental Technology \& Innovation, vol. 19, Article ID 100847, 2020.

[110] M. M. S. Bernardo, C. A. C. Madeira, N. C. L. dos Santos Nunes et al., "Study of the removal mechanism of aquatic emergent pollutants by new bio-based chars," Environmental Science and Pollution Research, vol. 24, no. 28, pp. 22698 22708, 2017.

[111] I. Anastopoulos, A. Katsouromalli, and I. Pashalidis, "Oxidized biochar obtained from pine needles as a novel adsorbent to remove caffeine from aqueous solutions," Journal of Molecular Liquids, vol. 304, Article ID 112661, 2020.

[112] Y. Liu, Q. Bai, Y. Liu et al., "Simultaneous purification of tea polyphenols and caffeine from discarded green tea by macroporous adsorption resins," European Food Research and Technology, vol. 238, no. 1, pp. 59-69, 2014.

[113] Q. Zhao, J. Yin, X. Wang et al., "Study on the adsorption characteristics of aqueous caffeine solutions on macroporous resins with hydrogen-bonding interactions," Indian Journal of Chemical Technology, vol. 25, no. 6, pp. 531-538, 2019.

[114] Y. Liu, Q. Bai, S. Lou, D. Di, J. Li, and M. Guo, "Adsorption characteristics of (-)-epigallocatechin gallate and caffeine in the extract of waste tea on macroporous adsorption resins functionalized with chloromethyl, amino, and phenylamino groups," Journal of Agricultural and Food Chemistry, vol. 60, no. 6, pp. 1555-1566, 2012.

[115] M. D. Saikia, "Revisiting adsorption of biomolecules on polymeric resins," Colloids and Surfaces A: Physicochemical and Engineering Aspects, vol. 315, no. 1-3, pp. 196-204, 2008.

[116] X. Tang, X. Wang, and J. Yan, "Water-swellable hydrophobic porous copolymer resins based on divinylbenzene and acrylonitrile. II. Pore structure and adsorption behavior," Journal of Applied Polymer Science, vol. 94, no. 5, pp. 2050-2056, 2004.

[117] C. H. M. Hofman-Caris, P. S. Bäuerlein, W. G. Siegers, J. Ziaie, H. H. Tolkamp, and P. de Voogt, “Affinity adsorption for the removal of organic micropollutants in drinking water sources; proof of principle," Water Supply, vol. 15, no. 6, pp. 1207-1219, 2015.

[118] Z.-B. Dong, Y.-R. Liang, F.-Y. Fan, J.-H. Ye, X.-Q. Zheng, and J.-L. Lu, "Adsorption behavior of the catechins and caffeine onto polyvinyl polypyrrolidone," Journal of 
Agricultural and Food Chemistry, vol. 59, no. 8, pp. 42384247, 2011.

[119] N. Ma, P. Wang, X. Kong, R. Shi, Z. Yuan, and C. Wang, "Selective removal of caffeine from tea extracts using macroporous crosslinked polyvinyl alcohol adsorbents," Journal of Separation Science, vol. 35, no. 1, pp. 36-44, 2012.

[120] M. Haddad, C. Oie, S. Sauvé, and B. Barbeau, "Adsorption of micropollutants present in surface waters onto polymeric resins: impact of resin type and water matrix on performance," Science of the Total Environment, vol. 660, pp. 1449-1458, 2019.

[121] S. Sanford, K. S. Singh, S. Chaini, and G. LeClair, "Study of natural adsorbent chitosan and derivatives for the removal of caffeine from water," Water Quality Research Journal, vol. 47, no. 1, pp. 80-90, 2012.

[122] M. N. V. Ravi Kumar, "A review of chitin and chitosan applications," Reactive and Functional Polymers, vol. 46, no. 1, pp. 1-27, 2000.

[123] E. F. Lessa, M. L. Nunes, and A. R. Fajardo, "Chitosan/waste coffee-grounds composite: an efficient and eco-friendly adsorbent for removal of pharmaceutical contaminants from water," Carbohydrate Polymers, vol. 189, pp. 257-266, 2018.

[124] S. A. Qamar, M. Ashiq, M. Jahangeer et al., "Chitosan-based hybrid materials as adsorbents for textile dyes-a review," Case Studies in Chemical and Environmental Engineering, vol. 2, Article ID 100021, 2020.

[125] U. Upadhyay, I. Sreedhar, S. A. Singh et al., "Recent advances in heavy metal removal by chitosan based adsorbents," Carbohydrate Polymers, vol. 251, Article ID 117000, 2020.

[126] M. Zhang, G. Ma, L. Zhang et al., "Chitosan-reduced graphene oxide composites with 3D structures as effective reverse dispersed solid phase extraction adsorbents for pesticides analysis," The Analyst, vol. 144, no. 17, pp. 5164-5171, 2019.

[127] M. F. Oliveira, V. M. De Souza, M. G. C. Da Silva, and M. G. A. Vieira, "Fixed-bed adsorption of caffeine onto thermally modified verde-lodo bentonite," Industrial \& Engineering Chemistry Research, vol. 57, no. 51, pp. 1748017487, 2018.

[128] M. F. Oliveira, M. G. C. Da Silva, and M. G. A. Vieira, "Equilibrium and kinetic studies of caffeine adsorption from aqueous solutions on thermally modified verde-lodo bentonite," Applied Clay Science, vol. 168, pp. 366-373, 2019.

[129] T. Shiono, K. Yamamoto, Y. Yotsumoto, and A. Yoshida, "Caffeine adsorption of montmorillonite in coffee extracts," Bioscience, Biotechnology, and Biochemistry, vol. 81, no. 8, pp. 1591-1597, 2017.

[130] K. Yamamoto, T. Shiono, Y. Matsui et al., "Changes the structure and caffeine adsorption property of calcined montmorillonite," International Journal of Geomate, vol. 11, no. 24, pp. 2301-2306, 2016.

[131] K. Yamamoto, T. Shiono, R. Yoshimura et al., "Influence of hydrophilicity on adsorption of caffeine onto montmorillonite," Adsorption Science \& Technology, vol. 36, no. 3-4, pp. 967-981, 2018.

[132] J. L. Sotelo, G. Ovejero, A. Rodríguez et al., "Study of natural clay adsorbent sepiolite for the removal of caffeine from aqueous solutions: batch and fixed-bed column operation," Water, Air, \& Soil Pollution, vol. 224, no. 3, Article ID 1466, 2013.

[133] S. Alvarez, J. Sotelo, G. Ovejero et al., "Low-cost adsorbent for emerging contaminant removal in fixed-bed columns," Chemical Engineering Transactions, vol. 32, pp. 61-66, 2013.

[134] A. Demba and K. Mohamed Sid'Ahmed, "Valorization of balanites aegyptiaca seeds from Mauritania: modeling of adsorption isotherms of caffeine from aqueous solution," Journal of Environmental Treatment Techniques, vol. 7, no. 3, pp. 450-455, 2019.

[135] G. Maia, J. Andrade, M. Oliveira et al., "Affinity studies between drugs and clays as adsorbent material," Chemical Engineering Transactions, vol. 57, pp. 583-588, 2017.

[136] A. Kiecak, L. Sassine, M. Boy-Roura et al., "Sorption properties and behaviour at laboratory scale of selected pharmaceuticals using batch experiments," Journal of Contaminant Hydrology, vol. 225, Article ID 103500, 2019.

[137] V. Martínez-Hernández, R. Meffe, and I. de Bustamante, "The role of sorption and biodegradation in the removal of acetaminophen, carbamazepine, caffeine, naproxen and sulfamethoxazole during soil contact: a kinetics study," Science of the Total Environment, vol. 559, pp. 232-241, 2016.

[138] S. Richards, P. J. A. Withers, E. Paterson, C. W. McRoberts, and M. Stutter, "Removal and attenuation of sewage effluent combined tracer signals of phosphorus, caffeine and saccharin in soil," Environmental Pollution, vol. 223, pp. 277$285,2017$.

[139] A. De Wilt, Y. He, N. Sutton, A. Langenhoff, and H. Rijnaarts, "Sorption and biodegradation of six pharmaceutically active compounds under four different redox conditions," Chemosphere, vol. 193, pp. 811-819, 2018.

[140] K. Delhiraja, K. Vellingiri, D. W. Boukhvalov, and L. Philip, "Development of highly water stable graphene oxide-based composites for the removal of pharmaceuticals and personal care products," Industrial \& Engineering Chemistry Research, vol. 58, no. 8, pp. 2899-2913, 2019.

[141] R. Zhao, Y. Yan, M. Li, and H. Yan, "Selective adsorption of tea polyphenols from aqueous solution of the mixture with caffeine on macroporous crosslinked poly(N-vinyl-2-pyrrolidinone)," Reactive and Functional Polymers, vol. 68, no. 3, pp. 768-774, 2008.

[142] S. O. Akpotu and B. Moodley, "MCM-48 encapsulated with reduced graphene oxide/graphene oxide and as-synthesised MCM-48 application in remediation of pharmaceuticals from aqueous system," Journal of Molecular Liquids, vol. 261, pp. 540-549, 2018.

[143] Y. Liu, Y. Liu, X. Wu et al., "Preparation of organic-inorganic hybrid porous materials and adsorption characteristics for (-)-epigallocatechin gallate and caffeine from the extract of discarded tea," Polymer Engineering \& Science, vol. 55, no. 10, pp. 2414-2422, 2015.

[144] J. Peternela, M. Silva, M. Vieira et al., "Synthesis and impregnation of copper oxide nanoparticles on activated carbon through green synthesis for water pollutant removal," Materials Research, vol. 21, no. 1, pp. 1-11, 2018.

[145] G. Leon, M. Aldás, V. Guerrero et al., "Caffeine and irgasan removal from water using bamboo, laurel and moringa residues impregnated with commercial $\mathrm{TiO}_{2}$ nanoparticles," MRS Advances, vol. 4, no. 64, pp. 3553-3567, 2020.

[146] P. V. dos Santos Lins, D. C. Henrique, A. H. Ide, C. L. de Paiva e Silva Zanta, and L. Meili, "Evaluation of caffeine adsorption by MgAl-LDH/biochar composite," Environmental Science and Pollution Research, vol. 26, no. 31, pp. 31804-31811, 2019.

[147] Y. R. Lee, M. Tian, S.-N. Kim, W.-S. Ahn, and K. H. Row, "Adsorption isotherms of caffeine and theophylline on metal-organic frameworks," Adsorption Science \& Technology, vol. 32, no. 9, pp. 725-735, 2014.

[148] B. C. Pires, F. V. A. Dutra, and K. B. Borges, "Synthesis of mesoporous magnetic polypyrrole and its application in studies of removal of acidic, neutral, and basic 
pharmaceuticals from aqueous medium," Environmental Science and Pollution Research, vol. 27, no. 6, pp. 6488-6504, 2020.

[149] K. Ortiz-Martínez, D. A. Vargas-Valentín, and A. J. Hernández-Maldonado, "Adsorption of contaminants of emerging concern from aqueous solutions using $\mathrm{Cu}^{2+}$ amino grafted SBA-15 mesoporous silica: multicomponent and metabolites adsorption," Industrial \& Engineering Chemistry Research, vol. 57, no. 18, pp. 6426-6439, 2018.

[150] I. A. S. Edwards, H. Marsh, R. Menendez et al., Introduction to Carbon Science, Butterworth-Heinemann Ltd., London, UK, 1989.

[151] S.-W. Nam, Y. Yoon, S. Chae, J.-H. Kang, and K.-D. Zoh, "Removal of selected micropollutants during conventional and advanced water treatment processes," Environmental Engineering Science, vol. 34, no. 10, pp. 752-761, 2017.

[152] R. Mailler, J. Gasperi, Y. Coquet et al., "Removal of emerging micropollutants from wastewater by activated carbon adsorption: experimental study of different activated carbons and factors influencing the adsorption of micropollutants in wastewater," Journal of Environmental Chemical Engineering, vol. 4, no. 1, pp. 1102-1109, 2016.

[153] X. Zhang, W. Guo, H. H. Ngo, H. Wen, N. Li, and W. Wu, "Performance evaluation of powdered activated carbon for removing 28 types of antibiotics from water," Journal of Environmental Management, vol. 172, pp. 193-200, 2016.

[154] M. A. Al-Ghouti and D. A. Da'ana, "Guidelines for the use and interpretation of adsorption isotherm models: a review," Journal of Hazardous Materials, vol. 393, Article ID 122383, 2020.

[155] J. R. de Andrade, M. F. Oliveira, M. G. C. da Silva, and M. G. A. Vieira, "Adsorption of pharmaceuticals from water and wastewater using nonconventional low-cost materials: a review," Industrial \& Engineering Chemistry Research, vol. 57, no. 9, pp. 3103-3127, 2018.

[156] H. M. Abdel-Aziz, R. S. Farag, and S. A. Abdel-Gawad, "Removal of caffeine from aqueous solution by green approach using Ficus Benjamina zero-valent iron/copper nanoparticles," Adsorption Science \& Technology, vol. 38, no. 9-10, pp. 325-343, 2020. 